Vol. 9, n² | 2005

Varia

\title{
«A Triumph of American Police Methods»: Representations of Police Work in Two Sensational Kidnap-Murder Cases of the 1920s
}

Petula lu

\section{(2) OpenEdition}

\section{Journals}

Electronic version

URL: https://journals.openedition.org/chs/288

DOI: $10.4000 /$ chs. 288

ISSN: 1663-4837

\section{Publisher}

Librairie Droz

\section{Printed version}

Date of publication: 1 December 2005

Number of pages: 9-42

ISBN: 978-2-600-01054-2

ISSN: 1422-0857

\section{Electronic reference}

Petula Iu, "«A Triumph of American Police Methods»: Representations of Police Work in Two

Sensational Kidnap-Murder Cases of the 1920s", Crime, Histoire \& Sociétés / Crime, History \& Societies [Online], Vol. 9, n² | 2005, Online since 26 February 2009, connection on 22 March 2022. URL: http:// journals.openedition.org/chs/288; DOI: https://doi.org/10.4000/chs.288

This text was automatically generated on 22 March 2022.

(C) Droz 


\title{
«A Triumph of American Police Methods»: Representations of Police Work in Two Sensational Kidnap- Murder Cases of the $1920 \mathrm{~s}^{1}$
}

\author{
Petula lu
}

\section{AUTHOR'S NOTE}

I wish to thank Eric Monkkonen for his support and guidance on my dissertation, «Arch Fiends and Moral Shipwrecks: Police Work, Criminal Insanity, and Masculinity in the Leopold-Loeb (1924) and Hickman (1927) Kidnap-Murder Cases», from which this article is excerpted. Thanks also to Ruth Bloch and David Wolcott for reading and commenting on early versions of the dissertation chapter; Steve Baule for reading an early version of this article; Cary Federman, for his comments on a version of the chapter presented at the annual meeting of the Social Science History Association, Baltimore (2003); the audience members at the panel - not only for their interest in the paper but also for their questions, which pushed me to clarify my points; and the anonymous reviewers of this article for their suggestions.

\section{Introduction}

1 In the early decades of the twentieth century, the police in the United States revamped their image as bumbling, incompetent, uneducated political lackeys and were transformed into professionals ${ }^{2}$. A key part of this transformation of the public image of the police involved the contribution of scientific detective work. The framing of detective work as grounded in science was bolstered by mainstream society's embrace of scientific knowledge, an embrace that was one of the signifiers of the nation's 
transition to modernity and which was articulated in the bureaucratization and scientific methods that were the hallmarks of Progressivism ${ }^{3}$.

2 Scientific crime work had been evolving since the latter part of the nineteenth-century and by the early decades of the twentieth, most law enforcement agencies in the U.S. were familiar with such scientific methods as the anthropometrics of the Bertillon system and fingerprinting. Over the course of the 1910s and 1920s there was an increase in the acceptance and proliferation of scientific crime detection, an increase that foreshadowed the later developments. Even so in the 1920s the police and crime work were still in the process of re-fashioning their image into a modern one and the press representations of the Leopold-Loeb (1924) and Hickman (1927) kidnap-murder cases offer two moments in which to analyze these image-making efforts. Contemporary observers had immediately deemed the Leopold-Loeb case the «crime of the century» and coverage of the case dominated the front pages of Chicago's newspapers for much of the late spring and summer of 1924. Hickman's crimes were nearly as sensational and, at one point, even seemed on the verge of eclipsing the notoriety of the Leopold-Loeb case. A close reading of the representations of police work as they appeared in the Chicago Daily Tribune, the Los Angeles Times, and the Los Angeles Examiner provides a glimpse into the discursive efforts that would eventually result in the construction of the image of the police as an institution and profession backed by the soundness and objectivity of science ${ }^{4}$.

3 The daily press representations of the two kidnap-murder cases did more than chart the work done by the police in the solving of the crimes ${ }^{5}$. While the disparity in the coverage - the rather sparse and none-too-thrilling images of the police in the LeopoldLoeb case as opposed to the lengthy and positive portrayals in the Hickman case - can be attributed to the different challenges presented the police in the two cases, they also reveal the extent to which the press was willing to aid in the public transformation of the image of the police from that of embarrassingly incompetent fools (popularly represented by the silent film images of the Keystone Kops) into professionals with special expertise in the arena of crime detection ${ }^{6}$. The process of professionalizing the police, along with the introduction of science into police work, continued throughout the first decades of the twentieth century. The representations of the police and their work in the Leopold-Loeb and Hickman cases illustrate the public images of the police at these points of transition as they proceeded to make themselves into professionals. Compared to the relatively minimal coverage of the police and police work in the Leopold-Loeb case, the effusive portrayals of the Los Angeles Police Department (LAPD) in 1927 reveal how, at least when provided the favorable conditions such as those of the Hickman case, the press was more than willing to jettison old images of ineffective police work in favor of the vision of an active, professional police force bolstered by the very latest in scientific methods in its fight against crime.

4 This article examines the press accounts of police work as occasional attempts at selfrepresentation and as exercises in press construction. As such, this is neither a topdown, power/control model, nor is it an anti-authoritarian, radical critique of the powers of the press and the police. Instead, I seek to situate press representations as cultural work. These were stories told to make sense of the inexplicable, to bolster selfimage, boost morale, and help foster a sense of public authority and status at a time when the American police, as an institution, was still in the early stages of professionalization. The ways in which the police and police work were framed in the 
two cases offer a contrast that reveals more than just the relations between a city and its relation to its police department ${ }^{7}$. Rather the different portrayals are a product of the different circumstances in which the two cases unfolded.

The police's intervention in the two cases were dramatically different - one appearing only after the fact and thus focused on the role of detection while the other was actively engaged in some degree of prevention as well as much detection work. This difference allowed for a variation in the opportunities afforded for press coverage, a variation that affected the extent and quality of the portrayals of police work and their respective departments. In the Leopold-Loeb case, the detection work was very much tied in with the work done by the State's Attorney's Office and this, along with the particulars of the case, led to limited press coverage of the role of police work. In stark contrast to this is the Hickman case where the press coverage included sustained, positive coverage of the Los Angeles Police. The much greater role played by the LAPD throughout the entirety of the Hickman case (including the successful identification and apprehension of Hickman) lent itself to the heroic narrative of the department presented by the press.

Ultimately my story is that of how the press accounts figured as one component of the narrative that served to preserve public order and engender feelings of safety. That the police's image (especially that of the LAPD) was given a significant shot of positive publicity along the way was incidental, the fortuitous outcome of a particular constellation of factors - a heady blend of youth, sex, violence, and money - that justified editors' decisions to devote an inordinate amount of editorial hours and numerous column inches to these stories which captured the public's imagination. Yet it is important to keep in mind that the influence and power of these press accounts was very limited and short-lived. In the years after the Leopold-Loeb case, the Chicago Police Department continued to be a site of corruption and inefficiency and the press would be unforgiving in its reportage of the department's problems. The same could be said of the LAPD, despite its glowing depictions in the Hickman case. When it was strategic to do so (for example, in the wake of the wide-spread panic following the kidnap-murder of Marion Parker), the press was willing to furnish positive portrayals of the force. But these positive depictions would give way as new stories of corruption and politics dividing the department would surface.

7 Newspaper accounts, because they are widely distributed and reach a cross-section of the population, can provide a valuable entrée into thinking about a culture's sensibility ${ }^{8}$. The choice of whether to focus on a crime and, if so, the resources and coverage devoted to the coverage of a specific crime (as reflected in the headlines and the sheer number of columns devoted to a story) are clues that provide some sense of the preoccupations and norms of the society in which the papers circulate ${ }^{9}$.

Newspapers provide narratives of crimes and their offenders, but they can also be seen as repositories and reflections of prevailing assumptions (about race, class, gender, criminality, punishment, and a whole host of other categories and conditions). The narratives present (or, at least, attempt to present) a coherent story to impose some sense and order to the disorder created by the crime. The stories, then, are rich tapestries in which the individual writer and editor's viewpoints are woven together with what they believe their perceived reader may or may not be thinking or assuming. While ostensibly relaying the facts and developments of a case, the stories are also engaged, in some degree, with a critique of society and a prescription of how things 
should be (this can be detected, for example, in terms of whether the offenders are depicted in a sympathetic light, or whether to focus on the victims).

But news is not always and only determined by those situated within the ranks of journalism. In looking at news and its transmission in eighteenth-century Paris, a time and locale that had much news but no newspapers as such, historian Robert Darnton has suggested that each era has its own methods of communicating information ${ }^{10}$. By investigating the methods by which information - knowledge - was transferred and circulated in the pre-newspaper society of Paris circa 1750, Darnton lays out a complex nexus in which privileged information such as intimate details about the goings-on of the courts as well as political discourse made their way from the site of incidence to different strata of society by way of various communication channels ranging from gossip and song to salons and, eventually, into print. Through an analysis of various modes of communication (such as songs, jokes, poems, police records, recorded gossip, and fact-based fiction) Darton argues for the need to consider the ways in which events (in this case, politics) gets framed for the public at the same time that the public is engaged and implicated in the process of the transmission of the very same information through their intervention into the telling, remembering, and recording of the stories and narratives. Darnton's article challenges the privilege of print culture in favor of a broader definition of communication that includes a multitude of oral, visual, and written mediums.

10 Following Darnton and the works of others in the study of the press, historian Gregory Shaya argues that investigations into

the power of news, the making of a mass public... reveal an understanding of news as not just a realm of political debate but a cultural practice that forms communities and shapes identities... The news report... is more than a report, it is an important site for the production, the maintenance, and the revision of a social imaginary. We should not suppose that there is one recipe for the making of a mass public, but crime, catastrophe, and crowds figure largely among the ingredients. Such scenes - centered on the broken bodies of victims or on the collective body of observers - are more than the occasion for cheap thrills, they are the opportunity for conversations about the social body ${ }^{11}$.

For Shaya, the crowd is not just a passive group of observers ${ }^{12}$. Shaya's crowd is a figure that serves multiple functions - legitimating the view of the press as well as serving as a new understanding of the public that is defined and united by emotions, sensations, and empathy. The mass press utilized the commonality provided by the consumption of sensational events such as crimes and disasters to provide a narrative that helped provide a sense of community. At the same time, it also helped shape, train, and determine the boundaries of appropriate behavior and emotional response (be it horror, empathy, and/or pity). This, in turn, influenced the terms of public debate and even policy regarding crimes and punishment.

11 The consideration of murder narratives as political acts and artefacts (through their delineation of the limits of socially acceptable behavior by drawing attention to the deviant) is not new to historians ${ }^{13}$. Perry L. Curtis, for example, situates the narratives of Jack the Ripper in their historical context by way of an analysis of fifteen London newspapers (representing viewpoints from across the political spectrum). He examines the press coverage of the killings to tease out the moral and political messages purported in these stories. Curtis's approach is informed by his treatment of «murder news as a social and cultural construct assembled by reporters who both influence and 
are influenced in turn by standards of approved behavior. News, in sum, is not just about politics, it is politics» ${ }^{14}$.

In looking at the narratives of the Leopold-Loeb and Hickman cases, I am looking at the sites where the boundaries of normative behavior are being drawn and contested, as well as how knowledge of new practices - such as police work - are introduced into the public domain. In my larger project, I investigate the press accounts of the LoepoldLoeb and Hickman cases - as the crimes unfolded and on through their trials - to situate these accounts as reflections framed by contemporary cultural, social, and intellectual assumptions regarding criminality, punishment, gender, and the police. These stories, in essence, chart the political faultlines along which existing and emerging ideologies engage in their skirmishes. In this article, I engage in an exploration of the press narratives of police work in these two sensational cases to delineate the contours of the public images of police work at a time when the process of professionalizing the police was yet incomplete. Though perceptions of the police as drunks and incompetents were fading, it would be a few more decades before the police would be identified as professional crime-fighters. The representations of the police and police work found in the press coverage of the Leopold-Loeb and Hickman cases are an indication as to where, on that continuum between fool and professional, the public's perceptions of the police fell in the 1920s.

\section{The Crimes}

13 On May 21, 1924, nineteen-year-old Nathan F. Leopold, Jr. and eighteen-year-old Richard Loeb embarked on their most «thrilling adventure» yet ${ }^{15}$. These precocious, highly educated, and extremely wealthy sons of members of Chicago's Jewish elite considered themselves to be superior beings in the vein of Friedrich Nietzsche's Superman. They believed that their superiority placed them above the laws that governed the masses and, to prove their superiority, they set out to commit «the perfect crime ${ }^{16}$. On that day in May they parked their rental car in the vicinity of the exclusive Harvard School as they waited for a likely prey to emerge from the school grounds. After waiting for some time they decided to drive around to search out a victim. Although a couple of candidates presented themselves, ultimately it was fourteen-year-old Bobby Franks who caught their attention. Franks was an acquaintance of Loeb's younger brother and on this afternoon, under the pretense of wanting to learn more about a tennis racket, Loeb lured Franks into the car for a ride. Once inside the car, Franks was hit over the head with a chisel and then suffocated with a cloth ${ }^{17}$. He died shortly thereafter.

It was after dark by the time Leopold and Loeb finally got out to the marshlands near Chicago's Wolf Lake. There they finished undressing Franks, poured hydrochloric acid over his face and body so as to disfigure him and thereby make identification more difficult, and then shoved the body into the culvert beneath the train tracks ${ }^{18}$. On the way home the pair mailed a ransom note and placed a call to the Franks family informing them that Bobby had been kidnapped, that he was safe, and that more information would be provided the next day.

The following morning the Franks were told to prepare a $\$ 10,000$ ransom and to await further instructions. That afternoon Bobby's father was instructed to take a cab to a specific drugstore where he was to wait for yet another phone call that would provide 
him with instructions for delivering the ransom. Shortly after receiving this call, confirmation arrived at the Franks home that an unidentified body found earlier that day was that of Bobby's. But for the difference of a few minutes, the ransom would have been delivered.

A week after the murder, Leopold and Loeb were picked up for questioning. Their alibi was that they had spent the afternoon and evening in Leopold's car, birdwatching and drinking in the park before spending the evening driving around and picking up two girls for a quick, anonymous sexual tryst. The alibi fell apart under the weight of other evidence and a damning revelation by the Leopold family chauffeur. The trial, with Clarence Darrow leading their defense, was a spectacular performance that captivated the attention of readers in Chicago and beyond with its lurid details of the individual life histories of the two defendants and the very explosive issue of whether they should be put to death for their crimes against Bobby Franks.

17 A few years after the Leopold-Loeb crime shocked the nation, yet another adolescent kidnapped and murdered another adolescent. Unlike Leopold and Loeb, nineteen-yearold William Edward Hickman did not come from a family of wealth and privilege. Nor was Hickman's victim from the ranks of the elite. Hickman was a well-liked, seemingly well-educated young man whose brutal killing and mutilation of a young girl generated one of the largest manhunts California had mounted up to that time.

On December 15, 1927, twelve-year-old Marion Parker left the campus of Mt. Vernon Junior High School with a well-dressed, well-spoken young man. School officials had called Marion to the office in response to the news brought by this young man that her father had had an accident and was calling for her. The young man confidently identified himself as an employee of the Los Angeles bank at which Marion's father was an executive. The pretext of an injured father asking for his daughter sufficiently convinced the school official that she should comply with the young man's request and release Marion into his custody. Later that afternoon Marion's twin sister, Marjorie, returned home to find her father in apparently good health and spirits. He had stayed home that day, his birthday. Marjorie told her family about the earlier incident with Marion and it was at that moment that the Parker family realized something terrible had happened to Marion. Shortly after this revelation the first of the kidnapping notes signed by "The Fox» arrived at the Parker home. Several other notes, telegrams, and phone calls followed over the next couple days, culminating in the ransom exchange on Saturday evening. At the exchange Marion's mutilated torso, her face made up with rouge and her eyelids sewn open, was returned to her father. The rest of her body divided into newspaper wrapped bundles and scattered in the general vicinity of neighboring Elysian Park and the Los Angeles River - was recovered the following day.

19 Angelenos were shocked by the news of the kidnapping and brutal murder of little Marion Parker. The city responded with a total commitment of its law enforcement resources to the search for her killer and a week later the culprit was captured. During the time of the manhunt and even after Hickman was captured, the daily press faithfully reported every action undertaken by the authorities in the search. Readers who followed the development of the case in the newspapers were exposed to the practices of police work and the art of forensic science. In the process the press accounts offered up an image of the LAPD as an active, professional organization powered by the methods of scientific investigation. 


\section{Police Work in the Leopold-Loeb Case}

the establishment of a citizen's commission to investigate the organization. This committee was yet another entry among the many systematic investigations into the workings of the criminal justice system that had begun with the 1922 Cleveland Survey and which continued to crop up periodically throughout the decade ${ }^{21}$. The Citizen's Police Committee was formed in 1929 out of a need to investigate the crime-reporting procedures of the police department as well as the problem of Chicago's high crime rate $^{22}$. The Committee investigated all aspects of the department and the result was a published report, Chicago Police Problems. Altogether the pages of the report outlined different aspects of the problems of the police department and possible solutions to these problems. The overriding premise guiding the formation of the investigative Committee and the report it produced was that «the police force as a whole is handicapped by a defective organization,» that the force as an entity was unequipped to handle the city's crime problem, and that «The entire history both of the city and of its Police Department shows that crime, disorder, and police ineffectiveness have been consistent features ${ }^{23}$.

In addition to these already unflattering characterizations of the Chicago Police Department, the chapter on criminal investigation provided an even more damning picture of the force. The chapter opens with the statement that

The essentials of a good detective bureau are realized whenever a sufficient number of persons, selected for common sense, vigor, integrity, and special aptitude, are employed under competent supervision to handle the cases necessarily requiring investigation by a headquarters unit ${ }^{24}$.

Since the report had already established that the police force as a whole was incompetent and useless, the rather quotidian expectations of a good detective bureau outlined here reads as an even more insulting indictment than just the claims of corruption and inefficiency. That these basic requirements were not met by those charged with carrying out one of the most important tasks of police work - the work of criminal investigation - offers, in very concrete terms, a glimpse at some of the problems faced by the department. Furthermore the report claimed that «The investigating personnel included a great many individuals who, according to their own admissions, owed their assignments to political influence ${ }^{25}$. The lack of qualified men in the department is especially glaring in the report's discussion on the Homicide section. The report stated, rightly, that

A crime with the significance of homicide... merits the attention of the highest type of specialized investigator, versed in criminal law, alert in observation, exact in reporting, quick to employ scientific aids, and of swift and accurate decision ${ }^{26}$.

Yet, unfortunately, once again the reality of the composition of the police force was found wanting when it was noted that «Special ability as a qualification was obviously not the inviolable rule in the choice of the men in this section $»^{27}$. Given this

Crime, Histoire \& Sociétés / Crime, History \& Societies, Vol. 9, n² | 2005 
observation, the Committee recommended that «only high-grade officers showing proficiency in handling homicide cases be assigned to this unit» ${ }^{28}$. Apparently the situation thus far was that a number of less-than-qualified men had been landing these assignments.

In addition to observations and recommendations about personnel the report also made an explicit call for the establishment of an identification unit. The report noted, rather frustratingly it seems, that «Private philanthropy has supplied what public officials were unwilling or unable to offer - a scientific crime-detection laboratory» ${ }^{29}$. While it was disappointing, perhaps even embarrassing, that the public sector had failed to fund such an endeavor as the Scientific Crime Detection Laboratory, the upside of this (or so the report suggested) was that this helped shield the lab and its findings from political influence ${ }^{30}$. The early decades of the twentieth century had witnessed law enforcement agencies experimenting with various forms of criminal identification ${ }^{31}$. These attempts, while illustrating each method's efforts to gain acceptance and prestige, also reveal how the practice of identification - criminal and crime scene were not yet routinized and standardized. That Chicago's police department had yet to establish an identification unit is evidence of this point. Clearly this was a police department that was far from modern and professional. Entrenched as it was in politics and cronyism, the department was unable to carry out its duties. With its members dominated by political appointments rather than well-trained recruits, the force was not equipped to do its job.

Aside from the rather sad state of the Chicago Police Department, so poignantly relayed in Chicago Police Problems at the decade's end, the lack of emphasis on police work in the Leopold-Loeb case could also, perhaps, be attributed to the way in which the mystery of Bobby Franks's murder was solved. Though much was made of the discovery of Leopold's eyeglasses near Bobby's dead body, the most significant factor that led to the unraveling of Leopold and Loeb's alibi was its discrediting by the testimony of the Leopold family chauffeur, Sven Englund.

25 In the days after the discovery of Bobby's body and prior to the arrests of Leopold and Loeb, the press reports provided an image of a police department furtively searching for the killer(s) in vain. The press covered the coroner's statements about the state of the body, as well as his speculations as to the events of leading up to the killing and even his opinion as to the character of the murderer. That the coroner was neither trained in police science nor detective work, and hence really not qualified to speak about what may be the characteristics of the murderer, did not seem to diminish his voice of authority in the least. The press still reported his thoughts as some kind of truth, printing Coroner Wolff's musings on what happened to Bobby the afternoon and evening of his kidnap-murder ${ }^{32}$.

Not only did Wolff theorize about what had happened to Bobby in the course of the kidnap-murder, he also posited that, given that the ransom letter was well-written, at least one of the culprits involved was intelligent and educated. Interestingly enough, the sophistication of the ransom letter was the subject of a story on the very next column $^{33}$. The story noted that the ransom letter, «with its faultless English, its scholarly diction, bore a striking resemblance to several such letters of fiction which appeared in a story, 'The Kidnaping [sic] Syndicate,' in the May 3 issue of the Detective Story Magazine» ${ }^{34}$. One could possibly argue then that the high quality of the writing in the ransom letter was not necessarily an indication of the culprits' education and 
intelligence (as theorized by Coroner Wolff) but merely evidence that they were avid readers of detective magazines.

Perhaps Coroner Wolff's unfounded statements about the murderer were considered legitimate because of the general acceptance of the coroner's office as the voice of authority when it came to pronouncing causes of death. The fact that the coroner, rather than a detective or representative of the police department, would be quoted so extensively in the press suggests either a lack of respect for the police in general or that police work had yet to acquire the status of a professional (which would have marked the theorizing about crimes and the understanding of the actions of criminals to be the realm of expert knowledge and hence the exclusive domain of the police). Moreover, the newspaper account noted that Wolff's theory was «as near as any official came to a logical hypothesis» as to what had happened, and that the Chief of Detectives Michael Hughes concurred with Coroner Wolff's theory ${ }^{35}$.

Throughout the press accounts of the Leopold-Loeb case scant attention was paid to the activities of the police. Though the images that were offered were not depictions of corruption and incompetence and, as such, could be considered an improvement in the public image of the police, neither were these images paeans to the possibilities of police work - investigative or scientific. Beyond the less-than-stellar reputation of the Chicago Police Department at this time, the lack of glory surrounding the descriptions of police activities in the Leopold-Loeb case can also be attributed to the fact that the police had very little to do with the solving of Bobby's murder. There were three elements which linked Leopold and Loeb to the crime: (1) Leopold's eyeglasses, found at the scene of the crime near Bobby's recovered body, (2) Sven Englund's testimony, and (3) the typewriter on which the ransom letter was written. Of these three components, it was Englund's testimony that prompted Leopold and Loeb to abandon their alibi and confess their crime.

Although much has been made of the eyeglasses by the press reporting on the case then and in subsequent accounts of the case since, in actuality the glasses alone would not have proven much other than that Leopold had been at the site of the crime. Tony Mankowski, an immigrant worker, was heading home after working the night shift at a millhouse when he came across Bobby's body. Shocked by his discovery he flagged down a crew of Pennsylvania Railroad workers who happened to be nearby. While looking around the vicinity of the body Paul Korff, one of the railroad workers, found a pair of eyeglasses. It was by accident that these glasses, initially believed to be Bobby's, were found. Only after the body was identified did the police learn that Bobby did not wear glasses.

Upon ascertaining that the glasses did not belong to Bobby, the police began the rather tedious work of trying to track down the owner of the glasses. This particular pair of glasses was identifiable by the unique and expensive hinges that held it together. Luck would have it that in the Chicago-area these hinges, produced by the Bobrow Optical Company of Brooklyn, were sold exclusively through Almer, Coe \& Company. Almer, Coe, a tony optometry store, had recently instituted an elaborate method of organization that made it possible to keep track of all its prescription glasses. The employees systematically combed their records - some 54,000 of them - and came up with the names of three people who had bought those hinges from them recently ${ }^{36}$. One of those names was Nathan F. Leopold, Jr. After a process of elimination - the other two 
names on the list had been able to produce their glasses - Leopold was called in for questioning.

31 At this point it was not clear that Leopold was a suspect though it was a little suspicious that he, unlike the other names on the list, was not able to produce the glasses when asked about them. But he had a plausible explanation. As an avid, and published, ornithologist Leopold often spent time in the woods and marshlands around Chicago and had even led small tours of birdwatchers out to the marshlands around Wolf Lake ${ }^{37}$. In fact he had been out in the vicinity just days - more specifically, the previous weekend - prior to the murder.

Initially the questioning was routine, since Leopold was not yet a suspect. According to one press account, the detectives were "Almost apologetic at the absurdity of their trip... Chatting with Nathan in his private library, they had found Richard, his chum, who then accompanied them to police headquarters $»^{38}$. The authorities felt they had to question Leopold because his glasses had been found near Bobby's body, not because they suspected that he had anything to do with the murder. Leopold and Loeb handled the questioning so well, so smoothly, that «More than one of the officials felt like apologizing for detaining them ${ }^{39}$. Moreover the "friendly poise of both the boys» dispelled what little suspicions the authorities had of their involvement in the crime ${ }^{40}$.

Leopold's explanation was not implausible but, when combined with Loeb's inconsistent testimony about his activities on the day of the kidnap-murder, the State's Attorney decided to proceed with a few more questions ${ }^{41}$. Adding to the questionability of Leopold's story was Paul Korff's statement that the glasses were clean when he found them ${ }^{42}$. By making this observation, he «helped to upset the alibi of young Leopold» who had posited that the glasses had been dropped some days prior to the discovery of Bobby's body ${ }^{43}$. While this inconsistency may have aroused suspicions, such statements were still not sufficient to compel Leopold to abandon his claims of innocence.

Leopold's presence and familiarity with the marshlands was easily explained by his well-known interest in ornithology. His interest in bird-watching allowed Leopold to confidently admit that he had been out at the marshlands, even near the culvert, the weekend prior to Bobby's death and that it was probably at this time that he had lost his glasses ${ }^{44}$. Thus the glasses in and of themselves offered a very weak link between Leopold (and Loeb) and the murder. Certainly the detectives who questioned Leopold thought that. During the initial hours of questioning Leopold was still confident that he was going to get away with the crime, undetected. Leopold was so cocksure of himself that he even made a public announcement to the press, stating quite magnanimously that he felt that the police were justified in questioning him and that he was more than willing to help the police solve this crime ${ }^{45}$.

Regardless of the level of guilt or discomfort the detectives may have experienced during the course of their questioning Leopold and Loeb, both the authorities and the two youths were aware that the glasses were insufficient evidence to link them to the crime. At most the positive identification of glasses only proved that Leopold had been in the area where Bobby's body had been dumped. For Leopold and Loeb the awareness of the tenuousness and insufficiency of the police's evidence probably added to the thrill of their crime. For the authorities to be so close to solving the crime, even to the point of questioning them about the glasses and yet ultimately failing to suspect that they were the culprits, let alone prove their guilt, seemed to add to the sense of triumph that had accompanied what they believed to be their success in committing 
the perfect crime. This knowledge of the weakness of the link provided by the glasses made it possible for Leopold and Loeb to have the breezy and brazen attitude they had during the course of their questioning ${ }^{46}$.

Loeb had been taken into custody and questioned mainly because he was with Leopold at the time that he was picked up by the police. And it was in the capacity of Leopold's alibi that Loeb was questioned. At this point the police had yet to find concrete evidence linking them to the crime and Leopold and Loeb recited their prepared story as to where they were the day Bobby was kidnapped and murdered. The alibi involved the two of them having used the Leopold family car, first to do some birdwatching and then to meet some girls. While all of this would have made a sound alibi, or at least one that would have been difficult to discount, the story fell apart when the chauffeur, Sven Englund, testified that it would have been impossible that the boys had taken the car since he had been working on it all day. With this testimony, Leopold and Loeb's alibi was shattered and their confession soon followed.

Given that the chauffeur's testimony came forth voluntarily without any prompting from the police officers questioning him, there was not much ground on which to enhance the image of police work. What Englund told the authorities contradicted Leopold and Loeb's seemingly airtight alibi and prompted their confessions. Without Englund's testimony it is likely that Leopold and Loeb would have stuck with their alibis. And without their confessions it is possible that Leopold and Loeb could have gotten away with the murder ${ }^{47}$.

Though it can be said that it was the result of police work that Leopold and Loeb were taken in for questioning (though the real work of identifying the eyeglasses had been carried out by employees of Almer, Coe and not by police officers), it can not be said that it was police work per se that solved the case. Leopold and Loeb had claimed that they had been in Leopold's car the day of the murder. Their calm demeanor throughout the time of questioning, their status, and their full cooperation with the investigation to the extent that they insisted they be kept in custody until the matter was cleared up - all seemed to suggest their innocence ${ }^{48}$. The State's Attorney's Office ordered the police to check out parts of the story and so it was that Sven Englund, the Leopold family chauffeur, was called in for questioning. But Englund was just «one of a dozen called to verify slight details of the alibi, smilingly and assuredly given by his employer's son ${ }^{49}$. There had not been any "expectation that he [Englund] knew of anything that might have a bearing on the crime, and the questions asked him were merely perfunctory ${ }^{50}$. Not only did the police not think that the chauffeur would have any important information to offer (this even though the use of Leopold's car was a key part of his alibi), the police didn't even ask Englund the right questions. It was «Of his own volition» that Englund provided the information that shattered Leopold's alibi ${ }^{51}$. His testimony to the police stated the impossibility of the boys' story given that Leopold's car had been in the garage until at least ten o'clock the night of the murder ${ }^{52}$. Englund remembered this because he had worked on the car's brakes that day. This statement «electrified the prosecutor's office» ${ }^{53}$. Up until that point prosecution attorneys had found Leopold and Loeb's detailed accounting of their whereabouts on the day of the murder so convincing that, if not for Englund's statement, they probably would have released the two boys. But Englund's statement shattered the boys' alibi and when Leopold and Loeb were told of his testimony, they abandoned their pretense and confessed ${ }^{54}$. 
The third piece of evidence against Leopold and Loeb was the typewriter. Here, too, the police had little to contribute. It was scientific police work that had determined that the typewriter on which the ransom had been written had «certain curious characteristics $»^{55}$. But, beyond that, the police had little to go on. Though they searched Leopold's rooms, they could not locate the typewriter with the identifiable peculiarities. It was only after Leopold's confession, and with his help, that the authorities were able to recover the «incriminating typewriter» ${ }^{56}$. Just hours after Leopold and Loeb confessed they led the police on a virtual re-enactment of the day of the crime. They showed the police the route they had taken that day and pointed out the various sites, including the lake where the typewriter had been dumped, where key pieces of evidence had been discarded ${ }^{57}$.

Once Leopold and Loeb had confessed attention immediately focused on trying to figure out why it was that they committed the kidnapping and murder. The motives for the killing were so baffling that Chicago Daily Tribune reporter John Herrick, in an early story about the case, wrote

Prosecutor and police officer, familiar with all the usual and unusual motives which make human beings kill each other - sex, money revenge, lust, greed, and all the rest - turned at last to the psychoanalyst as the only one who could straighten out the tangle of these minds, still in their 'teens, which could commit murder for the «experience» of it ${ }^{58}$.

This public assertion that not only were neither experienced upholders of the law nor enforcers of the law able to make sense of the crime but that, moreover, it was up to the psychoanalyst to uncover the meanings of the how and why of the crime, at once articulated the limitations of the authorities while elevating the status (through their expert knowledge) of the analyst ${ }^{59}$. The combination of the earlier reliance on Coroner Wolff's theorizing about the case and proclamations such as this one by reporters together suggest the precarious, yet-to-be-solidified position of the police as the authority on crime. Altogether these pronouncements helped increase the perception of Leopold and Loeb's mystique by highlighting the inexplicability of their actions.

The Chicago Police had a minimal role in the solving of Bobby's murder and the press reportage reflected this paltry participation. The police weren't quite the bumbling incompetents of old, but neither were they the active, professional, scientific crime fighters to come. With their image (and the realities of the profession) in a state of transition, the Chicago Police received scant attention in the press reportage of the Leopold-Loeb case. In stark contrast to this is the coverage of the Los Angeles Police in the Hickman case just three years later.

\section{Police Work in the Hickman Case}

The overwhelmingly supportive and positive narrative of the work by the Los Angeles Police Department in the Hickman case can hardly be explained away as merely the result of a pre-existing public relations campaign for positive public images. Certainly it is possible that some of the willingness to portray the LAPD in a positive light may be, at least in part, a holdover from the public relations efforts of August Vollmer's brief tenure as chief (1923-1924) ${ }^{60}$. But a more likely reason than that nebulous speculation is the very real and undeniable fact that the LAPD took a very active role in the Hickman case from the beginning. Unlike the Leopold-Loeb case where the role of the Chicago Police in the solving of the murder and the capture of the culprits was negligible, law 
enforcement officers in general, and the LAPD in particular, played a significant role in the way in which the Hickman case unfolded. Despite the LAPD's early failures in the case - for example, the unsuccessful trap set to capture the culprit at the time of the ransom exchange and the careless search of the building in which the crime occurred the successful identification of Hickman through the scientific method of fingerprinting and, more importantly, the show of force behind the concerted and coordinated efforts to capture Hickman, seemed to have more than redeemed them in the eyes of the press.

The very first stories on Marion's kidnapping appeared in the Los Angeles Examiner and the Los Angeles Times on Saturday, December 17. In this early coverage, less than fortyeight hours after Marion's abduction and a motive yet to be revealed to the public, the unusual circumstances surrounding the case had already gripped the public's interest and generated much police activity. The first newspaper story of Marion's abduction set up the hunt for her kidnapper as a race between police detectives armed with their «keen wits» against the "perverted cunning of a crafty kidnaper, in a colossal game of hide-and-seek» ${ }^{61}$. Though this was a very brief description of the detectives, the positive portrayal offered up a picture of intelligent officers hard at work in the fight against crime. This was especially powerful given that this sentence, occupying prime space on the front page of the newspaper, opened this very first story on Marion's kidnapping. The story continues with a sympathetic account of how the LAPD detectives, along with the Sheriff's department and members of the district attorney's staff, were struggling with the dearth of leads in the case. Despite the lack of evidence and leads the story reported that the officers were working hard in this race against time to track down Marion and her kidnapper. The police had even picked up a couple of suspects, both of whom were released after they had offered substantiated alibis. This lack of success by the police was not represented as a failing on their part.

Rather the recounting of police activities here, including the information about the released suspects, served the more significant point of showing that this was a police force very actively engaged in the task of finding the missing girl.

The cavalier manner of the abductor and the low social profile of the middle-class Parkers - that is, their very ordinariness - certainly contributed to the public interest in the case. The reporting of the ways in which the police investigation was frustrated by the lack of concrete clues or promising leads functioned to promote, rather than harm, the public image of the police as the protector of the public. This image was aided by the fact that, from the very beginning, the press reported that the law enforcement community had fully committed their resources in this hunt for the child and her abductor. On the first day of coverage the press was already proclaiming that the search for Marion was «one of the greatest manhunts in the history of Southern California» ${ }^{62}$. And this claim was not mere journalistic hyperbole. Law enforcement officers from across Southern California were involved in the search. Within Los Angeles a number of detectives were relieved of their regular duties and re-assigned to the Parker case while the District Attorney's Office also contributed its own detectives to the search ${ }^{63}$. The Parkers were not among the socio-economic elite of Los Angeles and the local authorities' commitment to the search for Marion was not a case of law enforcement favoring the wealthy and socially prominent. That Marion's abduction garnered such quick and intense response from law enforcement agencies suggests that the very ordinariness of the Parkers was what made Marion's abduction so terrifying. 
mystery surrounding the abduction (it was not until after Marion's dead and dismembered body had been returned that the ransom demands were reported in the press) confounded the public and intensified the fears of parents throughout the city. That the police had so fully committed to the search for Marion must have helped quell some of the anxiety coursing through the hearts and minds of Angelenos. The police's efforts were augmented by the efforts of the press, which had utilized the communications technologies of the telegraph, the telephone, and the radio to publicize descriptions of Marion, her abductor, and his car. Additionally the printed press reiterated the information broadcasted. Thus not only those police officers and district attorney's detectives who were professionally involved in the search had this precious information but nearly everyone in Southern California was privy to this knowledge and thereby involved in the search ${ }^{64}$.

In addition to the first day's reports on the commitment of large numbers of officers to the search, the second day's stories coupled news of the recovery of Marion's mutilated body with the message, once again, that the police had committed its resources to the case. The report that two thousand police officers were mobilized and ready to go and capture the kidnapper(s) presented the image of an active force ${ }^{65}$. As written up in the front page of Los Angeles Times the picture evoked was that of a mass gathering of officers waiting impatiently for the gate to be lifted so that they could charge out into the city streets in search of the fiend. The Los Angeles Examiner reported that, just moments after the child's mutilated body was returned to her father, «the entire resources of the [police] department were being called into play in an infinitely grimmer, fiercer, more determined manhunt to find the kidnaper [sic]- now the murderer - of the girl for whom the whole city had sought two days in vain» ${ }^{66}$.

The police may have failed in their attempts to locate the kidnapper and in their efforts to intercept the culprit when the first ransom exchange had been arranged, but that did not mean that the police were ready to give up. It was only after much resistance, and solely out of consideration for Marion's safety, that they agreed with the plan to allow Perry Parker to go forward with the ransom exchange, alone. After the failed attempt to foil the kidnapper's ransom plans Friday night, Perry and the police had decided that it was best if Perry adhered to the kidnapper's instructions rather than make yet another attempt to trap him for fear of endangering Marion's life. So it was that Perry drove to the meeting point alone - without informing the police of the meeting place - to reclaim his child in exchange for the ransom. The plan was that every police officer in the area would be ready to hunt down the culprit as soon as word was received that the child had returned to safety.

At the ransom exchange Perry Parker held up his end of the agreement, but the kidnapper did not. When a dead and dismembered Marion was returned to her father, the police were immediately notified and the already massive manhunt reached yet another level of intensity with the news of Marion's death:

Within a few moments [of Perry's recovery of Marion's body], the alarm had been flashed to the detectives waiting in readiness for instant call at central station. And in a few minutes more, the entire resources of the department were being called into play in an infinitely grimmer, fiercer, more determined manhunt to find the kidnaper - now the murderer - of the girl for whom the whole city had sought two days in vain. Radio broadcasting stations joined in the work of flashing the news of the ghastly ending of the search for the girl throughout the state, so that the newer search for the killer might begin without an instant's delay. Every police officer in 
the city was put on the case. All leaves cancelled. Every means of egress from Los Angeles were under guard within a short time of finding the child's body. And before 9 o'clock there was under way the most intense police campaign that Los Angeles has ever known...67 been able to locate Marion in time to save her life. This failure to prevent the tragedy propelled the police to devote even more energy and resources to locating the elusive kidnapper-murderer. When recounted in this light the failure of the police to save Marion Parker was not necessarily an indictment of their ability. Rather the presentation of the tragedy of Marion's murder as having occurred despite the police's efforts served to heighten the sense of the incredible cunning of this monstrous fiend rather than the ineptitude of the police.

As soon as the various newspaper-wrapped parts of Marion's body were found on the morning following the ransom exchange some 250 police officers were sent to conduct a house-to-house search in Elysian Park, the neighborhood where the newspaperwrapped bundles of Marion's body parts had been recovered ${ }^{68}$. While this was going on, other officers worked to track down the car - a 1927 Chrysler coupe, model 62 - used in the ransom exchange. Perry Parker had caught a glimpse of the license plate in his brief encounter with the culprit. Though the ends of the plate had been deliberately bent to conceal the full numbers, the partial numbers were sufficient to help the police locate the car in a parking garage downtown. The California plates turned out to be stolen and the car was soon identified as one that had been stolen from Kansas City, Missouri, back in November. From downtown the car was moved to the Lincoln Heights police station where it was taken apart and carefully searched for fingerprints and other possible clues ${ }^{69}$.

The portrait of a police force actively engaged in the hunt for Marion's abductor, now killer, dominated the stories on the third day of coverage. This time the front page of the Los Angeles Times announced that a "Giant Man Hunt» was under way. The story opened with a dramatic account of the capture of a suspect who was on an eastbound bus to Terre Haute, Indiana. He was captured when Los Angeles detectives, «Swooping down from the sky,» intercepted the bus in Las Vegas, Nevada ${ }^{70}$. The Los Angeles Examiner reported that the prisoner's fingerprints were taken in the jail there and immediately rushed by plane to Los Angeles. He was to be held in custody until the results of the fingerprint analysis returned ${ }^{71}$. A few paragraphs down in the Los Angeles Times story it was reported that the police had failed to find any evidence linking the suspect to the murder. But, once again, rather than this being regarded as a violation of an individual's rights or a failure on the part of the police, the presentation of police work in this account seems more committed to providing the image of an active police force. Given the widespread panic the murder had ignited, perhaps the press felt it was necessary to emphasize that the police really were out there working hard to track down the culprit. And if, along the way, a few innocents were rounded up as well, so be it. Better that than be accused of not doing enough or, even worse, allowing another atrocity to occur.

Monday's edition of the Los Angeles Examiner reported that that the «greatest manhunt in this section of the land» was on, with some four thousand law enforcement officers involved ${ }^{72}$. Special police bulletins were printed and distributed by motorcycle police to various parts of the state. In addition, «Every road in every direction was guarded» in the attempt to catch the as yet unidentified murderer ${ }^{73}$. Locally, «Retired officers have

Crime, Histoire \& Sociétés / Crime, History \& Societies, Vol. 9, n² | 2005 
been recalled to duty» as were those active officers who had been on leave or on vacation $^{74}$. As the scope of the manhunt increased with each desperate passing hour, other law enforcement agencies in the state, including the California National Guard, jumped to aid those in Los Angeles search ${ }^{75}$.

As recounted in the press, the hunt for the kidnapper-murderer was more than the usual routine display of officers dutifully following orders to track down a criminal. Deemed «one of the most brutal recorded here,» the murder had touched a nerve that incited law enforcement officials to throw themselves into the search. Frustration with the ease with which Marion had been abducted, their failure to prevent her death, the mutilation of her body, and the elusiveness of the culprit all combined to anger «the police department to white heat,» generating «like wildfire a surge of determination» to find the man behind the awful crime ${ }^{76}$. Such depictions of law enforcement officials' dedication to the search suggest that the officers, beyond carrying out their duties as commanded, somehow had a personal stake in finding and arresting the culprit. Police officers, much like the rest of the residents of Los Angeles, had been shaken by the kidnapping and brutal murder. In response they committed themselves to the manhunt.

During those first days of coverage what added to the general panic and the sense of the perpetrator's perversion were the ransom notes he had sent to the Parkers, the contents of which had been published in their entirety in Sunday's newspapers. The ransom notes provided some material with which to paint a portrait of the culprit. Even so, until the police identified the kidnapper-murderer, they and the press could only construct from abstraction. All that changed on Monday when the police made a positive identification of the perpetrator. Readers of Tuesday's newspapers were informed that «Shortly before dawn the greatest manhunt in the history of California began when 2,800 members of the Los Angeles Police Department, 2,000 deputy sheriffs and members of the constabulary and every available peace officer began systematic search for the suspect» ${ }^{77}$.

The identification of the suspect was a triumph for the LAPD. The police department's fingerprint expert, Lieutenant H. L. Barlow, had successfully matched the fingerprints from what was believed to have been the car used in the ransom exchange to a set of fingerprints in the police database ${ }^{78}$. The prints belonged to nineteen-year-old William Edward Hickman, convicted of seven counts of forgery just the previous summer ${ }^{79}$. This identification of the fingerprints solved the mystery of the identity of the kidnappermurderer. With that information law enforcement officials were able to provide all involved in the manhunt - from law enforcement agencies to the press to the public with photos and detailed descriptions of the suspect. Even before the fingerprints were found on the car and positively identified by Barlow, police officers had lifted prints on the ransom notes to help with identification. Copies of those prints had been sent to the state bureau of criminal identification and investigation in Sacramento where they were checked against a database with 260,000 sets of the prints of known criminal offenders in the state ${ }^{80}$. While they were busy going through the database, Barlow used the prints from the car and, by hard work and luck, was able to come up with a match first ${ }^{81}$. With this identification the police, the press, and the public were finally able to put a name and a face to the elusive criminal. Armed with this information the manhunt switched from that of a search for an unidentified fugitive to an identified 
one whose physical characteristics were broadcast throughout the state and whose photo was splashed across the pages of newspapers.

Both the police and the public regarded the match of the fingerprints as definitive proof that Hickman was the culprit. Eyewitness testimony - such as the descriptions and identification by the school official who had had contact with Hickman the day of Marion's abduction - was good, but it was not as convincing and (supposedly) infallible as scientific proof. Fingerprinting, with its aura of scientific method and precision, smacked of objectivity and therefore appeared more legitimate ${ }^{82}$. When the prints on the ransom notes were matched with those on the car and they, in turn, matched the prints on Hickman's police identification card, it was all but decided that Hickman was the fiend who had signed the ransom notes as «The Fox.» This confidence was further cemented when the fingerprints taken from various articles found in the Bellevue Arms apartment - believed to be the site of the murder - also matched those on the identification card $^{83}$. Though the apartment was supposedly rented to a «Donald Evans,» the fingerprints found on such innocuous items as a milk bottle, glass, and sugar bowl matched those of Hickman, thereby confirming suspicions that Evans was an alias employed by Hickman ${ }^{84}$. With the fingerprints as corroborating evidence, the police confidently pronounced that «Hickman is unquestionably the man» ${ }^{85}$.

In addition to examining fingerprints, the police also considered handwriting to be worthy of analysis. In yet another demonstration of scientific police work, the ransom notes were «subjected to microscopic examination» as handwriting expert J. Clark Sellers compared the writing in the ransom notes against the writing samples obtained from Hickman after his forgery arrest ${ }^{86}$. Only after placing the writing samples under the microscope for analysis did the expert then declare that they were the work of the same person. This confirmation of a match in the handwriting was viewed as part of the «strong chain of iron evidence» that positively linked Hickman to the crime ${ }^{87}$.

Driven by fears that Hickman would escape punishment for the horrors he had perpetrated on Marion (and, by proxy, Angelenos), the search for him intensified. Neighboring counties and states joined in the hunt as the geographic scope of the search widened. News and details of the case were spread by the press and by law enforcement organizations. The LAPD distributed throughout the West (and beyond) 50,000 copies of special «police bulletins, giving all useful information in the manhunt $\aleph^{88}$. These specially prepared four-page bulletins, headed by the news of a $\$ 25,000$ reward, contained detailed descriptions of Hickman and his car as well as reproductions of Hickman's photo, his fingerprints, and his handwriting. Also included were excerpts from some of the ransom letters and a complete summary of the kidnapmurder. These bulletins were sent to law enforcement agencies around the country as well as to high traffic areas such as gas stations and post offices ${ }^{89}$. Every mode of transport and communications technology available - from autos and planes to the telephone and telegraph - were used to get the word out ${ }^{90}$. In conjunction with the stories carried in the press, these bulletins helped disseminate information about Hickman and the crime across the country.

That there was an appetite and need for the official information provided by the bulletins is evidenced by the numerous arrests of Hickman look-alikes in various parts of the country. The numerous arrests also attest to how other cities were keeping a close eye on, and at times were directly involved in, the hunt for Hickman. For example, just two days after the identity of the kidnapper-murderer was splashed 
across the front pages of newspapers, the press reported that residents in nine cities including San Francisco, Kansas City, and Chicago - had either spotted or captured Hickman ${ }^{91}$.

The impressive display of inter-agency cooperation across the city, county, and state, and the outpouring of voluntary aid by Los Angeles area residents showed the spread of a manhunt that seemed to know no bounds. Even law enforcement agencies across the northern and southern borders of the U.S. got involved in the manhunt as «The net for the kidnap-killer had been spread from the Mexican border - in fact, even into Mexico - to the Canadian border and beyond; and from the Pacific to the Mississippi» ${ }^{92}$. Perhaps what is even more impressive about the international cooperation was that these efforts did not arise at the behest of Los Angeles authorities but instead were initiated by the Canadian and Mexican authorities themselves ${ }^{93}$. The horrors of the kidnapping and killing of a young girl, made all the more gruesome by the way in which her body had been returned to her father, aroused sentiments that transcended national boundaries.

While the fingerprinting and handwriting analysis were examples of the ways in which the police were using new methods for identifying suspects, the representation of the combination of old-fashioned police work and the newer scientific methods was most pronounced in the reports on the apartment searches. Police had located the apartment after discovering some identifying marks on towels that had been found with Marion's body. On the towels had been monogrammed the name of the Bellevue Arms apartment building. From that, and the fact that the location of the building was very close to where the parcels of Marion's body had been found, the police were able to ascertain that the killer had stayed at the Bellevue Arms. Every inch of the apartment was searched, every loose thread and spot analyzed. Such a meticulous search yielded evidence that proved Hickman had been in the apartment and that the murder had been committed there. Yet the means by which articles such as the uneaten half of a Brazil nut or the stains in the apartment bathroom were transformed into evidence also served to show-off the scientific methods of police work ${ }^{94}$. Under the microscope, not only were experts able to determine for certain that the stains were blood but they were also able to put a time frame - Saturday - on when those stains had been left. This, combined with the finding of pieces of newspaper that correlated with those used to wrap Marion's dismembered body parts, provided further proof that the police were indeed in the killer's apartment ${ }^{95}$.

In addition to accounts of the police laboratory's findings, what also commanded much of the press's attention were the various reports - toxicology, autopsy - from the coroner's office. Whether Marion had been drugged or poisoned, whether she was dead or alive at the time of dismemberment, whether she had been "criminally assaulted»these were questions that were posed by the press and the public and which were answered by the experts conducting tests on Marion's body. The press reported that, "Working with all the resources of modern science at his disposal, County Chemist R. J. Abernathy is busy night and day in testing the remains of Marion Parker for poison ${ }^{96}$. This image of a very busy chemist at work in the scientific lab was presented in conjunction with a report on the theory then being circulated that perhaps Marion was already dead, or at least drugged to the point of immobilization, by the time she was transported to the apartment. The police advanced this theory to help account for their failure to find any of her fingerprints - despite a «microscopic examination»- in the 
apartment ${ }^{97}$. Somehow it didn't occur to the police detectives that, perhaps, Marion may have been restrained and therefore the absence of her fingerprints inside the apartment was due to her lack of freedom of movement and not necessarily because she was already dead. But the theory was presented in the press in such a way that shed light on the manner in which the police came up with their theories. And despite being proven to be wrong later (at least according to Hickman's confession), the story showed how the police combined the findings culled from scientific applications with logical deduction, thereby demystifying the process of police work as well as legitimating it with the authority of science ${ }^{98}$.

The scientific police work conducted by investigators was presented in a positive light throughout the press coverage of the Hickman case. As police slowly pieced together evidence to help their reconstruction of the events, scientific tools such as chemical analyses allowed them to gain greater certainty that they were on the right track to accumulating evidence that would provide the foundation for a solid case against Hickman. The press recounted in detail every fiber, every hair, every stain uncovered by the police in their search of the apartment. And each bit of evidence helped the police reconstruct the timing of the events that led up to the kidnapping and murder of Marion.

The search for Hickman - «one of the greatest manhunts in the history of the nation» came to an end with his capture in Echo, Oregon, on Thursday, December 22, exactly one week after the abduction ${ }^{99}$. With Hickman in custody, the terror that had gripped the city since news of the abduction first surfaced finally released its hold ${ }^{100}$. Now that the hunt was over, the focus of attention quickly turned to speculations on the how's and the why's of the crime as well as to the legal process that would bring to trial, and punish, the kidnapper-murderer-fugitive.

Shortly after Hickman's arrest, the press offered up a summary list of the evidence accrued by the police in their detailed search of Hickman's apartment and the results of the analyses of their contents to construct a convincing case against him for public consumption ${ }^{101}$. That there was the backing of science - namely the expert analyses of fingerprints and blood - helped make the findings seem more objective, and therefore more convincing.

The application of scientific knowledge in the service of police work gained even greater public authority when the press reported on the findings of a chemical analysis of the apartment's plumbing pipes. The analysis had been ordered after the discovery of particles, believed to be blood and possibly human flesh, in the gooseneck of the sink. This analysis would yield «one of the most vital links in the chain that is expected to put a hangman's noose around the slayer's neck» if the particles did prove to be what they suspected ${ }^{102}$. Earlier chemical analysis had already revealed that stains found in the apartment were blood. Now, authorities believed, if the particles found in the pipes did prove to be blood and flesh, then that would be conclusive evidence that the dismemberment had taken place in Hickman's apartment ${ }^{103}$. This was an important piece of evidence since Hickman, by now in police custody, had confessed to the kidnapping but was claiming that the murder had been done by an accomplice at an unnamed location ${ }^{104}$.

68 Almost immediately after Hickman's arrest, law enforcement officials declared his identification and capture a «triumph» of police work ${ }^{105}$. The fingerprint identification of Hickman made it possible for authorities to positively identify him while the 
reproduction of photographs of him made his face instantly recognizable. Throughout the coverage of the hunt for Hickman, over and over it was the scientific evidence such as the matching of the fingerprints and the analyzing of the blood at the scene of the murder - that were used repeatedly to legitimize the claim that Hickman was indeed the man responsible for the crime.

As the train transporting Hickman from Oregon entered California, Hickman made a new confession in which he took full responsibility for both the kidnapping and the murder of Marion Parker. Exactly what prompted Hickman to make this admission will remain unknown. But there is no doubt that the material evidence which the police detectives and crime lab experts had amassed had already convinced the press that Hickman was the sole responsible party. Whether, and to what extent, this knowledge persuaded Hickman to make the full confession is open to speculation. But it is possible that, given the overwhelming amount of «scientific» evidence against him, he decided that it would be in his best interests if he made the confession voluntarily.

\section{Conclusion}

70 The representations of police work in the press coverage of the Leopold-Loeb and the Hickman cases differed dramatically. While acknowledging that there were explicit ties between the various newspapers and the cities in which these crimes occurred and that the relation between the press and politics is a complicated one, these complex ties alone do not adequately explain the difference in the coverage of these two cases. Rather, I suggest that what drove and shaped the narratives were other factors, namely the actual crime-solving and detective work by the police and the level of threat perceived by the general public.

71 Part of the difference in coverage can be attributed to the variations within the crimes, particularly in the ways in which each was resolved. One difference is the relatively minuscule role played by the Chicago Police in the Leopold-Loeb case as opposed to the very prominent role of the LAPD in the Hickman case. This is not to say that the Chicago Police had not worked hard on the Leopold-Loeb case. Rather the discoveries made by the Chicago Police were much more the result of work done in conjunction with the State's Attorney's Office and/or the cooperation of Leopold and Loeb. This is in contrast to the dramatic step-by-step unveiling of detective work (mistakes and successes uncovered through a process of trial-and-error) that was so much a part of the narrative of the Hickman case. As such, the press was able to provide a much more detailed picture of police work, weaving into their reportage the image of an active police force as well as transmitting information about the ways in which scientific methods such as fingerprinting and blood analysis helped make possible the identification of the culprit.

72 Coverage of police activities in these two cases was shaped by the degree of police intervention in the successful resolution of the respective crimes. At the most basic level, the greater degree of involvement of the police in the solving of the crime in the Hickman case translated into greater coverage in the press. Moreover, it is possible the Chicago Police did not get the kind of boost that the LAPD got because the level of threat, as perceived by the public, was not the same. It is possible that, because the victim in the Leopold-Loeb case was Jewish and a member of Chicago's economic elite, the crime - random and inexplicable as it was - did not generate the kind and degree of 
mass panic that the Hickman case, with its targeting of a white child of the middleclass, did. The sex of the victims also figured in the construction of the public perceptions of the crimes and the fears they generated. The image of a victimized girl perhaps because of unarticulated fears of sexual dangers - provoked much greater panic than that of the victimization of a boy. The fears of sexual defilement were much more pronounced and sustained in the Hickman case because the victim was female and the perpetrator male. There were fears of perversion in the Leopold-Loeb case, but those fears of sexual defilement (pertaining as they do to a marginalized subset of society) were not as imminent and familiar as that of the more commonplace dangers faced by an adolescent girl. That also may have contributed to the different ways in which the cases resonated with the public. Finally, at no point in the coverage of Bobby's murder, even before the murderers were found, was there a pronounced sense of fear that other children would be targeted.

In contrast the city of Los Angeles (with ripple effects across the nation) was gripped with fear from the moment that news of the kidnapping and murder of Marion Parker broke. This sense of widespread panic may have helped the image of (or, at least, the public's relation to) the Los Angeles Police in that, despite their corruption and politicization, they were the official symbol of the law and the institution to which most people turned for help in times of crisis. In the panic that followed Marion's abduction and murder, the press constructed the image of an active, can-do police force to help quell the public's fears. This faith in the force generated much publicity and it was fortunate for the LAPD that they successfully apprehended Hickman. The manhunt, which was a cooperative effort among various law enforcement agencies, showed the might and reach of the law. The scientific crime detection work that made use of the identification of latent fingerprints on the getaway car and in Hickman's apartment to identify Hickman brought much positive attention to the new methods employed by the police. The evidence, so dramatically reported in the press, convinced the public of Hickman's guilt, even before his confession.

Both the Leopold-Loeb and the Hickman cases fascinated the reading public. Yet the interest in the sensational accounts of the crimes and their outcomes suggest a multiplicity of motivations behind the narratives. The fascination with Leopold and Loeb was more akin to that with a circus sideshow, entranced as readers were by the freakishness that is contained within the continuum of human behavior. The crimes against Bobby Franks always seemed slightly distant and removed. This otherness of Leopold and Loeb, in conjunction with the sex of their victim, too may help account for why some young women could respond to Loeb, at least, with professions of love. In any case the press accounts fed on their difference - be it of education/intelligence, class status, ethnicity/religion, and/or sexuality. In contrast, throughout the press coverage of the Hickman case can be detected a sustained undertone of fear. This fear drove the public need for an overt display of security and stability, a feat accomplished by the press constructions of an active and able police force. In the end the public need for a sense of order combined with the fortuitous developments that accompanied the solving of the murder of Marion Parker and the subsequent manhunt for Hickman to generate a climate that welcomed extremely positive portrayals of police work and the Los Angeles Police Department. 


\section{BIBLIOGRAPHY}

Alix, E. K., Ransomkidnapping in America: 1874-1974: the creation of a capital crime, Carbondale, Southern Illinois University Press, 1978.

Booth, C. B., The kidnaping syndicate, Detective story magazine, New York, Street and Smith Corporation, 1924, 66, 2, pp. 1-47.

Chicago Daily Tribune.

Citizen's Police Committee, Chicago police problems, Chicago, University of Chicago Press, 1931.

Cohen, P.C., The murder of helen jewett: the life and death of a prostitute in nineteenth-century New York, New York, Vintage Books, 1998.

Cole, S. A., Suspect identities: a history of fingerprinting and criminal identification, Cambridge, Harvard University Press, 2001.

Curtis, P.L., Jack the ripper and the London press, New Haven, Yale University Press, 2001.

Darnton, R., Presidential address: an early information society: news and the media in eighteenth-century Paris, The american historical review, 2000, 105, 1, pp. 1-35.

Domanick, J., To protect and to serve: the lapd's century of war in the city of dreams, New York, Pocket Books, 1994.

Duggan, L., Sapphic slashers: sex, violence, and american modernity, Durham, Duke University Press, 2000.

Fass, P.S., Making and remaking an event: the Leopold and Loeb case in american culture,

The journal of american history, 1993, 80, 3, pp. 919-951.

Forbes, G., The direst murder in the history of chicago, part 2, Liberty: a weekly for everybody, New York, The Colorato Corporation, 1924, 1, 9, pp. 19-24.

Friedman, L.M., True detective, Studies in law, politics, and society, 1994, 14, pp. 9-24.

Gottlieb, R., Wolt, I., Thinking big: the story of the los angeles times, its publishers and their influence on southern California, New York, G.P. Putnam's Son's, 1977.

Hall, S., C. Critcher, T. Jefferson, Clarke, J., Roberts, B., Policing the crisis: mugging, the state, and law and order, New York, Holmes \& Meier Publishers, Inc., 1978.

Halttunen, K., Murder most foul: the killer and the american gothic imagination, Cambridge, Harvard University Press, 1998.

Harvey, D., The condition of postmodernity: an inquiry into the origins of cultural change, Cambridge, Blackwell Press, 1990.

Higdon, H., Leopold and Loeb: the crime of the century, Urbana, University of Illinois Press, 1975, 1999.

$\mathrm{Iu}, \mathrm{P} .$, Arch fiends and moral shipwrecks: police work, criminal insanity, and masculinity in the LeopoldLoeb (1924) and Hickman (1927) kidnap-murder cases, Ph.D. dissertation, University of California, Los Angeles, 2004.

Lane, R., Policing the city: Boston 1822-1885, Cambridge, Harvard University Press, 1967. 
Law enforcement in Los Angeles: Los Angeles police department (august vollmer, chief), annual report, 1924, introduction by Joseph G. Woods, New York, Arno Press, 1974.

Levin, M., Compulsion, New York, Carroll \& Graf Publishers, Inc., 1956,1996.

Los Angeles Examiner.

Los Angeles Times.

McLaren, A., A prescription for murder: the victorian killings of dr. thomas neill cream, Chicago, The University of Chicago Press, 1993.

McLaren, A., The trials of masculinity: policing sexual boundaries, 1870-1930, Chicago, The University of Chicago Press, 1997.

Monkkonen, E., Homicide in New York, Los Angeles and Chicago, The journal of criminal law and criminology, Northwestern University School of Law, 2002, 92, 3 and 4, pp. 809-822.

Monkkonen, E., Police in urban America: 1860-1920, Cambridge, Cambridge University Press, 1981.

Pendergast, T., Pendergast, S., (Eds.), The international dictionary of films and filmmakers, volume 2, $4^{\text {th }}$ edition, Detroit, St. James Press, 2000.

Shaya, G., The flâneur, the badaud, and the making of a mass public in France, circa 1860-1910, The american historical review, 2004, 109, 1, pp. 41-77.

Srebnick, A.G., The mysterious death of mary rogers: sex and culture in nineteenth-century New York, New York, Oxford University Press, 1995.

Terry, J., An american obsession: science, medicine, and homosexuality in modern society, Chicago, University of Chicago Press, 1999.

The american journal of police science, 1931, 2.

Walker, S., A critical history of police reform: the emergence of professionalism, Lexington, D.C. Heath and Company, 1977.

Walker, S., Popular justice: a history of american criminal justice, $2^{\text {nd }}$ edition, New York, Oxford University Press, 1998.

Walkowitz, J.R., City of dreadful delight: narratives of sexual danger in late-victorian London, Chicago, The University of Chicago Press, 1992.

Wendt, L., Chicago tribune: the rise of a great American newspaper, Chicago, Rand McNally \& Company, 1979.

White, Dr. W., Report: the Franks case: a psychiatric diagnosis and interpretation of the two defendants, (1924), Northwestern University Special Collections, microfilm box no. R-87-1.

Woods, G., The police in Los Angeles: reform and professionalization, New York, Garland Publishing Inc., 1993.

\section{NOTES}

1. Original quote, referring to the capture of William Edward Hickman, reads: «Chief of Police James E. Davis termed the apprehension of the fiendish slayer a triumph of American police methods and the American press, working as a unit in an emergency» Los Angeles Examiner, 23 December 1927, 5. 
2. This generalization of the image of the early police as inept functionaries arises, in part, from the existing contemporary images of the constable and night watch system. The constable and night watch, which in the U.S. date back to the colonial era, were the precursors of the modern police system. For a brief account of this early history in the U.S. context, see Lane (1967, chapter 1); Monkkonen (1981, chapter 1); Walker (1998, chapter 1). While the modern police system in the U.S. was largely modeled on the London Metropolitan Police (founded in 1829), it is necessary to keep in mind that the police in the U.S. and in Europe not only emerged and professionalized at different rates but also out of different conditions as a result of varying political systems and political conditions. Historian Samuel Walker offers an examination of the process of the professionalization of the police in the U.S. in the late $19^{\text {th }}$ and first third of the $20^{\text {th }}$ century in terms of the developments of careerism, managerial efficiency, ideals of public service and social reform, and the education and training of police officers. See Walker (1977).

3. My use of modernity is informed by my readings of Harvey (1990) and Terry (1999). Terry uses modernity as a term to «invoke a historical period distinguished by particular material definitions, including the expansion of industrialized production and massive urbanization, the emergence of consumer capitalism, the proliferation of scientific disciplines and technology, and the rise of technocratic administrative governing. Related to these historical developments, the term modernity connotes a way of thinking that privileged key notions. Paramount among these is the notion of progress, an idea cherished by moderns according to which 'advanced' civilizations are imaged to be moving ever-forward, and 'civilized' humans are engaged in an ongoing process of gaining a more complete understanding and control of the world's resources... With a pronounced interest in enlightenment and advancement, modern authorities sought to analyze what constituted the human being, to delineate its various types, and to predict its modern behavior. Modernity, then, is distinguished not only by the human subject becoming the object of scientific inquiry but also by a broad cultural fascination with the self and its complexities» Terry (1999, pp. 11-12). The Progressive Era (1900-1917) in U.S. history was a period marked by various social, economic, and political reforms loosely guided by the belief in the need to address and rectify social ills through the expansion of government so as to protect the public interest from uncontrolled private gain.

4. For this article I focused primarily on these three newspapers. For my discussion of the Leopold-Loeb case I relied primarily on the coverage in the Chicago Daily Tribune. My reasoning for this include: (1) In Hal Higdon's well-respected, detailed account of the case, Leopold had stated that the Chicago DailyTribune had offered one of the most accurate accounts of the case. Higdon (1999, p. 347). Given that Leopold, whom I consider to have been actively engaged in the construction of the public record of his identity and of the case at specific points throughout 1924 (and, even more conscientiously, in the decades following) favored the account presented in the Chicago Daily Tribune, I think that it is useful to look at just what image the newspaper did present its readers; (2) moreover Higdon concurred that the Chicago Daily Tribune offered one of the most complete coverage of the case; and (3) the Chicago Daily Tribune claimed an average daily circulation of 594,938 and a Sunday circulation of 916,562 in May 1924. The numbers increased to a daily circulation of 619,298 and 915,552 for Sundays in June and then decreased in July to a daily circulation of 612,572 and 891,040 for Sundays. These were substantial numbers in a city whose total population numbered 2,701,705 according to the 1920 census and 3,376,438 in the 1930 census. See Fass (1993) for an excellent discussion on the evolution of the representations of the Leopold-Loeb case, based primarily on the coverage in the Chicago Daily News. For the Hickman case, I looked at the two major Los Angeles newspapers at the time. According to the 1920 census, the population of Los Angeles city was 576,673. By 1930 this number had grown to $1,238,048$. The figures for the county were 936,455 in 1920 and 2,208,492 in 1930. The Los Angeles Times in November 1927 claimed a daily circulation of 162,201 and 234,935 for Sundays. For December the daily circulation was 170,934 daily and 238,387 for Sundays. The numbers 
increased again in January 1928with a daily circulation of 180,236 and a Sunday circulation of 244,518 . For the same time period the Los Angeles Examiner claimed that its circulation was over 1.7 million copies per week. Clearly the combined circulation of these two papers reached a significant number of the city's population.

5. Newspaper accounts, like other forms of print culture, can be problematic in that they are historical products that betray their social, political, and economic contexts. That said, for a general sense of a particular period's ethos, newspapers can offer a useful lens through which to view a time, place, and/or event since newspaper reports are one of the primary ways in which a significant sector of the public gets its information. As Ernest Kahler Alix has noted in his sociohistorical study of kidnapping in the United States, «Newspapers are the main source of detailed information about crime for most members of the social audience. It is upon the basis of this information, biased as it may be, that evaluations [on the deviancy or criminality of certain acts or behaviors] are made and actions taken [in terms of how the law enforcement and/or legal community should respond to the act(s)]. Alix (1978, p. xi). In his discussion of the validity of using newspapers as a source for gauging a society's reaction(s) to crime, Alix writes: «The mass media [meaning mass communications media such as the press, radio, and television] are the main sources of public information about crime and laws. In addition to simple news reporting, members of the sector provides editorials and commentaries containing normative evaluations of crime and laws. The normative evaluations reflect beliefs held by members of the sector about the heinousness of deviant acts and about the deterrability of potential offenders by legal punishment threats. As one writer has observed: 'A conception of crime is presented in the mass media. That conception, diffused throughout society, becomes the basis for the public's view of reality.'» Alix (1978, pp. xix-xx).

6. The «Keystone Kops», created by director Mack Sennett, was a recurring band of comedic characters who appeared in films from 1914 to the 1920s. According to the American Film Institute's Catalog the first appearance of the Keystone Kops was in «Tillie's Punctured Romance». This 1914 film, directed by Sennett, is considered to be the first American-made, feature-length comedy and also featured Charlie Chaplin's film debut. Pendergast and Pendergast (2000).

7. The owners of the Chicago Daily Tribune, Robert R. McCormick and Joseph M. Patterson, were actively involved in politics at the local, state, and national levels. On a personal level and through the paper, they critiqued the influence of monopolies and trusts and fought crime, vice, and corruption in the city. Their forays into politics were not always successful (McCormick was a Progressive Republican, Patterson a Socialist), but that did not take away from the continued prosperity and expansion of the paper that began when McCormick and Patterson took the helm of the paper in 1911. For a detailed discussion of the history of the paper, as well as McCormick's and Patterson's political ties, see Wendt (1979). Interestingly enough, Patterson was also instrumental in introducing the «Dick Tracy» comic strip to the American public. The original character of Tracy was named «Plainclothes Tracy» and it was Patterson who compelled the strip's creator, Chester Gould, to change the name to «Dick Tracy». The contract also required Gould to consult with Patterson on the strip's storyline. The strip, which first appeared in the NewYork News in 1931and the Chicago Daily Tribune in March, 1932, «was the first to glamorize police work on the basis of careful research» Wendt (1979, p. 405). While today the Los Angeles Times is considered a world-class newspaper, in the 1920s it was a conservative, anti-labor, rabid, parochial paper that was very much embroiled in local politics and tied to the establishment. There was a close relationship between the Los Angeles Times and the LAPD, especially when this relationship is considered in terms of the links between the publisher of the paper and the chief of the police. Harry Chandler, as one of the most powerful men in Los Angeles, had actively used his newspaper as a force for the growth and expansion of the city. As part of this boosterism, Chandler did concern himself with the public image of the city. This need for a positive image of 
the city included the façade of a safe city in which the police were active in protecting its citizens. Yet this protection was framed in terms of the instability posed by organized labor. And although Chandler was interested in the control of crime, the crimes that garnered the most attention and manpower were those related to vice and corruption, not violence. It would be naïve and disingenuous for me to argue that Chandler and his paper did not have a political and economic stake in how the LAPD was publicly represented since that image was tied in to the larger public picture of the safety and desirability of the city of Los Angeles. Even so, the power and influence of his paper was not monolithic and uncontested. Furthermore, while acknowledging that there were clear stakes in how the LAPD was represented, I do not think that this takes away from my argument that the Los Angeles press's representations of the police and police work were greatly helped by the actual work done in the solving of the Hickman case and that, had the developments in the case been less dramatic, the narratives could have been less glowing and heroic. The Los Angeles Examiner, a competing Hearst paper, too offered a similarly positive and glamorized image of the police and police work. This seems to suggest that it was this combination of the fears generated by Hickman's crimes and the active (and successful) crime-solving by the LAPD that produced these supportive narratives of the police. For a discussion of Chandler and the history of the Los AngelesTimes, see Gottlieb, Wolt (1977). For a history of the LAPD, see Woods (1993); Domanick (1994).

8. A discussion that problematizes the ways in which news is produced and how it reflects as well as shapes the social context in which it circulates can be found in Hall et al. (1978), especially Chapter 3. They argue that «'News' is the end-product of a complex process which begins with a systematic sorting and selecting of events and topics according to a socially constructed set of categories» Hall et al. (1978, p. 53). This selection process is evidenced by the categories in which a newspaper is organized (for example, categories such as local news, domestic news, foreign news, and sports) as well as the allocation of human resources (for example, regular reporters versus special reporters). This selection and organization process already exerts influence over the kinds of stories that make it into the news. In addition to this process are the editorial decisions that prioritize the stories that get produced - whether it gets on the cover or the back page, or column space allotted to a story. These decisions are guided by pre-determined, professional ideas as to what is considered newsworthy. Another component in the production of news is that of the construction of the story: «This involves the presentation of the item to its assumed audience, in terms which, as far as the presenters of the item can judge, will make it comprehensible to that audience. If the world is not to be represented as a jumble of random and chaotic events, then they must be identified (i.e. named, defined, related to other events known to the audience), and assigned to a social context (i.e. placed within a frame of meanings familiar to the audience)... An event only 'makes sense' if it can be located within a range of known social and cultural identifications» Hall et al. (1978, p. 54).

9. «Things are newsworthy because they represent the changefulness, the unpredictability and the conflictual nature of the world. But such events cannot be allowed to remain in the limbo of the 'radom' - they must be brought within the horizon of the 'meaningful'. This brining of events within the realm of meanings means, in essence, referring unusual and unexpected events to the 'maps of meaning' which already form the basis of our cultural knowledge, into which the social world is already 'mapped'. The social identification, classification and contextualisation of news events in terms of these background frames of reference is the fundamental process by which the media make the world they report on intelligible to readers and viewers. This process of 'making an event intelligible' is a social process - constituted by a number of specific journalistic practices, which embody (often only implicitly) crucial assumptions about what society is and how it works» Hall et al. (1978, pp. 54-55).

10. Darnton (2000).

11. Shaya (2004, p. 46). 
12. Shaya suggests that, in contrast to the flaneur (that iconic figure of the alienation of modernity), the badaud offers an alternate figure that is equally a product of modern society: «The figure of the Flaneur captures the experience of the modern city so well - urban alienation, the psychology of distraction provoked by the tumult of urban stimulation, the social and gender configurations of the city in the age of consumer capitalism; as a figure of scholarly analysis, it has proved quite useful. But the figure of the badaud offers us insight on a parallel experience of modernity. In the mass press of Paris, it promised a symbolic solution to the very problems of modernity expressed in the figure of the Flaneur. Where the Flaneur experienced alienation and dislocation, the badaud partook in a community forged in the spectacle of suffering and outrage. The badaud-in-the-press expressed a utopia of the crowd, a vision of the individual-becomecollective in the face of human indignity. This badaud was the imaginative glue in the making of a mass audience, a new public, an 'imagined community' (to recast the term of Benedict Anderson) not of the nation but of right-feeling people.» Shaya (2004, pp. 76-77).

13. See, for example, the works of Cohen (1998); Curtis (2001); Duggan (2000); Halttunen (1998); McLaren (1993; 1997); Srebnick (1995); Walkowitz (1992).

14. Curtis (2001, p. 4).

15. Leopold and Loeb had a history of engaging in various crimes, ranging from such petty endeavors as cheating in card games to much more serious acts such as arson, car theft, and burglary.

16. The «perfect crime» was more than one that escaped detection. As revealed by Loeb during his psychiatric examination with Dr. William Alanson White, «A perfect crime, from his point of view, did not mean any particular kind of crime; that is, robbery, forgery, murder, or what not, but a crime in which the police were baffled; where there were no clews [sic]; which was carried out according to the original scheme; and resulted in an unsolved mystery; its degree of perfection was in proportion to the number of complexities and difficulties overcome, and to the opportunity it offered for cleverness and finesse, and the maximum of newspaper publicity. It was also desirable that it should be right in this community where he lived so that it would be a topic of discussion for weeks and months in the papers, among his friends and in his family.» White (1924, p. 9).

17. The question as to who - Leopold or Loeb - dealt the actual blow that killed Franks has never been fully resolved. In their confessions of the crimes against Franks, each accused the other of being the culprit. The general consensus among those who have written on the case is that Loeb was the one responsible.

18. While the motivation for pouring acid over the face and body was, most ostensibly, to complicate the possibility of identification if, and when, the body was found, the psychological motivation for such an act has been read as a desire for the eradication of Jewish identify by at least one author. Meyer Levin, in his psychoanalytically-inflected fictional treatment of the Leopold-Loeb case, cast the act of pouring acid over the face and genitals specifically in terms of the desire to eradicate the outward identificatory signs of Jewishness: "Judd [ the fictional corollary of Nathan Leopold] took this acid, and he said he poured it on the face, and he poured it on the penis.' He became silent. 'They said it was with the idea that a boy might be identified - ' 'Look, they knew better than that,' Willie said. 'Well, it was circumcised - he could be identified as a Jew. In fact, that's how I came to identify him.' 'And wasn't that part of it, for Judd?' Willie said, rather softly. 'Wasn't that one of his conflicts? Didn't he have to obliterate the problem of being a Jew? To dissolve it, so that the sign would be gone, the mark in the flesh...'» Levin (p. 406). For a more detailed analysis of Levin's treatment of the Leopold-Loeb case, see Fass (1993); a brief discussion is also included in my dissertation. See Iu (2004, chapter 1).

19. Citizen's Police Committee (1931. p. 1). 
20. Smith was the resident police expert with the National Institute of Public Administration, New York City, when the Operating Committee of the Citizen's Police Committee invited him to head up the study of the workings of the Chicago Police Department.

21. The Cleveland Survey, which yielded the 1922 report, Criminal Justice in Cleveland, was the first non-partisan, scientific study of the criminal justice system and it served as a template for a number of other commissions at the state and federal level over the years. Most of the early reports were conducted at the local or state level. The first national study of the criminal justice system was the 1929 National Commission on Law Observance and Enforcement, more commonly known as the Wickersham Commission. The Commission published its findings in fourteen volumes in 1931. Its volume on The Police was written by August Vollmer, the founder of the Berkeley Police School and one of the earliest and most vocal advocates for the professionalization of the police. After the Wickersham Commission (1929-31) there was a threedecade gap before the next federal crime commission was created. The President's Commission on Law Enforcement and Administration of Justice, more commonly known as the President's Crime Commission, was created in 1965 under the Johnson administration. For more on crime commissions, see Walker (1998, pp. 152-157, 202-206).

22. According to the Chicago Citizen's Police Committee, there were 2,722 homicides (murders and manslaughters) committed in the ten years between 1920 and 1929. This figure was offered as yet more proof of the inefficiency of the police department. Citizen's Police Committee (1931, p. 3). For the year 1929, the report noted that there were 471 homicides. Ibid. (1931, p. 130). For an age standardized look at Chicago homicide rates for the period 1880-1930, see Monkkonen (2002, figure 2, p. 820). The figure shows that by 1930 Chicago's homicide rate had reached over 10 per 100,000. This figure was more than double the 5 per 100,000 rate of Chicago and New York City in 1880. That said, the 1930 rate masks the reality that, in terms of crude numbers, the number of Chicago's homicides actually peaked in 1925.

23. Citizen's Police Committee (1931, p. 5).

24. Ibid. (p. 119).

25. Ibid. (p. 119).

26. Ibid. (p. 130).

27. Ibid. (p. 130).

28. Ibid. (p. 131).

29. Ibid. (p. 130).

30. Ibid. (p. 130). The Scientific Crime Detection Laboratory, affiliated with Northwestern University, was founded in 1930 and was «organized, not for profit, under the laws of Illinois, for the purpose of engaging in the practical applications of all branches of Science to the detection of crime». This mission statement was published in the inside of the organization's official publication, The American Journal of PoliceScience. The organization also offered variety of courses in police training and «scientific methods of crime detection». For example, in its Fall Course announcement for 1931 (the first year of instruction), it offered instruction in the following subjects: General Methods of Crime Detection, Elementary Psychology, Methods of Detecting Deception, Questioned Documents, Elementary Chemistry, Physics and Toxicology, Uses of UltraViolet Rays, Firearm Identification (Forensic Ballistics), Legal Medicine, Criminal Law, and Literature of Police Science (1931, p. 352). The organization, which offered its first course in Police Training in February 1932, claimed faculty from Northwestern University and the University of Chicago, members of the police departments of Chicago and the vicinity, members of various Government agencies including the Department of Justice and the Treasury Department, as well as members of various Illinois State bureaus (1931, pp. 532-537).

31. Over the course of the late-nineteenth and early-twentieth centuries, police departments experimented with both anthropometrics and fingerprinting as systems of criminal 
identification. For the story on how fingerprinting came to replace anthropometrics as the preferred method, see Cole (2001).

32. Coroner Wolff's theory, which "excludes the pervert idea», is as follows: "At least two men decided to kidnap Robert Franks and hold him for ransom...They enticed him - or dragged him into a big gray Winton automobile as he was walking homeward on Ellis avenue at 49th street. The bruises on his head indicate they struck him three times to keep him quiet. The boy resisted with all his youthful strength, and when it appeared likely his cries would be loud, they gagged him with hand or cloth. The fright, the choking sensation, his violent tugs to release himself, brought on a hemorrhage, and death. Then, having a body to conceal and the primary purpose of their crime - ransom - not yet attained, they decided to go through with their plans. Perhaps they had the letter written then. They must have been educated, one at least, to have drafted that demand in such perfect English. That would signify intelligence, a dangerous attribute in a criminal, and render him devoid of either conscience or the ability to feel remorse. Greed would be the controlling passion and dead or alive, they intended to cash in on Robert Franks, the millionaire's son. The letter writer called Mrs. Franks on the phone a few hours after her boy was dead. He assured her the boy was safe and would remain unharmed if the instructions to follow were followed and the money paid over. I believe one of them was acquainted in the neighborhood where they secreted the body. I am having a check made on a disorderly house in that vicinity to get a roster of the patrons. If the killer is a degenerate he may have frequented the house I have in mind» Chicago Daily Tribune (24 May 1924, p. 2).

33. The newspaper actually re-printed the two letters - the fictional one from the magazine and the actual one received by the Franks family - side by side for comparison. Each warned against notifying the police, stipulated the ransom amount and designated note denominations, and instructed the recipient to await further instructions. See Ibid. (24 May 1924, p. 2). A reading of the two letters suggests that, while the Franks ransom letter may have been modeled after the fictional letter in content, the actual writing in the Franks letter seems more sophisticated than that of the fictional one.

34. The story, by Christopher B. Booth, appeared in the May 3, 1924 edition of Detective Story Magazine. The story involved two ex-convicts and their successful kidnapping of a doctor's wife for ransom. The ransom note sent by Leopold and Loeb bears some resemblance to the one that appears in the story. But the most striking parallel is that in the story it was a significant point that the note was well-written - a sign that it had been written by «a most unusual criminal. An educated man» - and that this mark of education was "certainly something new in kidnapping» Booth (1924, p. 26). A friend of the doctor was presented as an amateur detective - a man who «had shown an inclination to dabble with criminology» and who considered «Anything easy enough for the police to solve» as not worthy of his attention. Ibid. (p. 27). In the end, as this story unfolds, even this learned man's deductive brilliance was no match for the wits of the even more cunning cons. This story of an educated, intelligent criminal getting away with a kidnapping clearly provided even more fuel to Loeb's already active imagination and, given the timing, probably boosted his confidence in the belief that a well-executed crime could elude detection. After the crime, especially in light of the fact that the kidnap-murder of Bobby Franks occurred less than a month after the publication of this story, it is also not surprising that detectives familiar with the story would find some parallels between fact and fiction. The Chicago Daily Tribune story did not actually name the person who made the link between the two ransom letters. It stated that James Gourtland, the secretary to Chief of Detectives Hughes, had arranged the letters side-by-side for police detectives to examine. But this statement was written with such ambiguity that it is unclear who-Gourtland, another member of the police, or someone outside of the police department altogether - made the actual connection between the two letters. Wendt, in his history of the Chicago Daily Tribune, writes that it was actually the Daily Tribune's police reporter, James Doherty, who had made that link. Wendt (1979, pp. 481-482). 
35. Chicago Daily Tribune (24 May 1924, p. 2).

36. Higdon (1999, pp. 76-77).

37. Leopold had had a longstanding love for birds and kept close to 3,000 bird specimens in his home. His interest, and knowledge, was so great that he was even granted special permission from the city of Chicago to shoot birds in the public parks. In 1923, during a trip to northern Michigan, Leopold discovered a nest of rare Kirtland's warbler. The discovery resulted in Leopold's presentation of a paper on the birds, titled «The Kirtland's Warbler in its Summer Home», at the annual meeting of the American Ornithological Union. The paper was published in the organization's official journal, Auk, vol. 41 (1924, pp. 44-48). Higdon (1999, pp. 18-19).

38. Forbes (1924, p. 23).

39. Ibid. (p. 19).

40. Ibid. (p. 23).

41. At first Loeb offered that he had spent the day with Leopold but denied that they had been together in the evening. This contradicted Leopold's story that the two of them had spent the entire day and evening together, first at the park and then driving around with two girls they had picked up on the streets. According to Higdon Loeb changed his story to match Leopold's account of the day's events only after he learned that Leopold was sticking to their prepared alibi. Initially Loeb had resisted telling the prepared alibi. When Leopld and Loeb had constructed the alibi, they had agreed that they would stick with it if they were picked up for questioning within a week but abandon the story after that. They were picked up eight days after the murder - but seven days after the last call to the Franks home - and so there was some confusion as to whether to stick to the alibi. Leopold chose to do so and, eventually, Loeb did too. For more on the alibi, see Higdon, chapters 9 and 10. The inconsistent details in Loeb's story were, for a time, explained away by his claim that he had been drinking that day. According to the Chicago Daily Tribune (31 May 1924, p. 2), «Richard told practically the same story, excepting in parts where he said he was 'hazy,' because of the drink he had taken». The New York Times (31 May 1924, p. 1), simply reported that «The evening of the kidnapping he spent with Loeb, he [Leopold] insisted, first in Lincoln Park and later riding about with two girls, finally ending the night at a cabaret. Loeb insisted that he was not with Leopold that night».

42. Korff found what turned out to be Leopold's glasses while he and several other members of his crew were pulling Bobby's body out of the culvert. Higdon (1999, pp. 39-43). While the newspaper quoted Korff as stating that the glasses were clean when he found them, it is important to note that in Higdon's account the glasses were dirty «from having lain on the muddy ground» Ibid. (p. 43). It is unclear where Higdon ascertained this information but his account of the case is often considered the most authoritative account of the Leopold-Loeb case and, as such, I feel that it is necessary to at least make note of this alternate description of the state of the glasses.

43. Chicago Daily Tribune (1 June 1924, part 1, p. 4).

44. When asked if he had ever been near the culvert where Bobby's body had been discovered, Leopold answered "'Why, certainly. I have been there at least fifty times. I am interested in ornithology, you know, and that was an advantageous place from which to watch young birds.' Confident of his abilities, Leopold volunteered the information that he had been at the culvert on the Saturday and Sunday preceding the Wednesday on which the boy's body was jammed into the water pipe». Forbes (1924, p. 23).

45. The actual text of his dictated statement reads: «The police are more than justified in holding me in custody for a limited period, as I am the victim of an unusual set of circumstances. For I was out at the culvert the Saturday and Sunday before the glasses were found. I am sorry this happened only because it will worry my parents. But I'll certainly be glad to do what I can to help the police.»Ibid. (p. 23). 
46. In Forbes's account Leopold and Loeb's questioning by the authorities was presented as if it was a game. Questions were hurled at them and they «caught them suavely and tossed back the answers». Ibid. (p. 19).

47. The police, with the help of Leopold and Loeb, would later recover more physical evidence (including a blood-soaked robe used to cover Bobby's body) linking the youths to the murder. There is no way of determining whether the police would have found this other evidence by themselves. Moreover it is difficult to say whether the found evidence would have been sufficient to incriminate Leopold and Loeb without the addition of Englund's damning testimony and the confessions it prompted.

48. According to a front page story that appeared on 1 June, 1924, in the New York Times, «The attitude of Leopold and Loeb when they were first arrested inclined the State's Attorney and the police to doubt their guilt. Both asserted their innocence and courted the fullest investigation, even to saying they did not desire freedom until they had been fully cleared, a position endorsed by their parents... The suspicions of the State's Attorney became strongly aroused when Loeb contradicted Leopold and declared he was not with his chum in the evening. Checking up on Leopold's story when doubt began to be cast on it, Mr. Crowe learned from the Leopold family chauffeur that the youth's car had not been out of the garage on the day of the kidnapping». In the previous day's paper, Leopold was quoted as saying, «No, it would be criminal on the part of the police to let me go now on account of the glasses. I thought all along that the glasses were the best clue for the police to follow, never thinking they were mine. I didn't know I had lost them but now I am sure I did, and it was on one of my many trips to that vicinity. I think the last time I was there was on the Sunday preceding the Franks murder» New York Times (31May 1924, p. 16).

49. Ibid. (1 June 1924, p. 1).

50. Ibid. (I June 1924, p. 1).

51. Ibid. (1 June 1924, p. 1).

52. Ibid. (1 June 1924, p. 1).

53. Chicago Daily Tribune (1 June 1924, part 1, p. 2).

54. Ibid. (1 June 1924, part 1, p. 3).

55. Forbes (1924, p. 23).

56. Ibid. (p. 24).

57. Chicago Daily Tribune (1 June 1924, p. 1); a map showing the routes appeared in the same day's paper, (part 1, p. 2). The New York Times (1 June 1924, p. 1), reported that «The police automobile was driven to Jackson Park to the spot where Leopold said the pair had thrown first the keys of the typewriter, then the rest of the machine. Police were left to drag the lagoon».

58. Chicago Daily Tribune (1 June 1924, part 1, p. 3).

59. A more extended discussion on the role of psychiatric experts in the Leopold-Loeb case can be found in my dissertation. See Iu (2004, chapter 4).

60. Vollmer (1876-1955) was a key figure in the move towards the professionalization of the police in the U.S. For example, during his tenure as chief of the Berkeley Police Department, he introduced a police training program and recruited graduates from the university into the force. In 1923 the Los Angeles Crime Commission invited Vollmer to Los Angeles to reorganize the city's corrupt and inefficient police department. During his one year tenure as the chief of the LAPD Vollmer restructured the organization, established a police academy, and did much to enhance the public image of the police. At the end of his term, he produced a landmark two-volume analysis detailing his findings on the LAPD and recommendations for change. The report, Law Enforcement in Los Angeles: Los Angeles Police Department (August Vollmer, Chief), Annual Report, 1924 was not publicly available until it was reprinted in 1974 as part of the Criminal Justice in America series.

61. Los Angeles Examiner (17 December 1927, p. 1).

62. Los Angeles Times (17 December 1927, p. 1). 
63. According to the Los Angeles Examiner (17 December 1927, p. 1), «More than a hundred operatives of the police department and the district attorney's staff have been thrown into the search for the girl and the kidnaper. Moreover, throughout Southern California, every peace officer in every community has been notified of the case and given a complete description of the girl and the stranger». See also the Los Angeles Times (17 December 1927, p. 1).

64. As it was reported, it read as if literally every resource of the law enforcement community was committed to the manhunt. For example, «Descriptions of both Marian [sic], the kidnaper and his car - as complete as police have them - have been broadcast over Southern California by telephone, telegraph and radio. Every peace officer in this section of the country has that information. Citizens have been asked, over the radio and via the newspapers, to lend what aid they can in the quest. Every available man in the police department and in the district attorney's detective staff has been assigned to the hunt and as fast as other sleuths are finishing their assignments to other cases they too are being thrown into the search for the girl» Los Angeles Examiner (17 December 1927, p. 2).

65. According to the Los Angeles Times (18 December 1927, p. 1), «Concentrated in every police station in Southern California were more than 2000 police officials awaiting the flash that the kidnapers had appeared and with the tragic message telephoned to Chief of Detectives Cline's office by the father, the greatest manhunt in the history of the city was on».

66. Los Angeles Examiner (18 December 1927, p. 2).

67. Ibid. (18 December 1927, p. 2).

68. Ibid. (19 December 1927, p. 2).

69. Ibid. (20 December 1927, p. 3).

70. Los Angeles Times (19 December 1927, p. 1).

71. Los Angeles Examiner (19 December 1927, p. 2).

72. Ibid. (19 December 1927, p. 1).

73. Ibid. (19 December 1927, p. 2).

74. Ibid. (19 December 1927, p. 4).

75. Around the state, other law enforcement agencies lent their resources to aid those in Los Angeles. This aid increased as news of the murder spread and as the killer continued to successfully thwart the efforts of authorities in the Los Angeles area. «Even airplanes were called into service yesterday. The California National Guard, with authorization from Sacramento, offered the manhunters the use of the guard's planes, available here, to transport officers to distant towns, when reports and clews [sic] began coming in yesterday morning - clews that could not be overlooked, and tending to indicate that the killer had fled in some certain direction after eluding the police net spread here for him»Ibid. (19 December 1927, p. 2).

76. Ibid. (18 December 1927, p. 2).

77. Ibid. (20 December 1927, p. 1).

78. His high profile involvement in the Hickman case probably helped Barlow advance his career. It is also possible that it helped raise his recognition and status among the law enforcement community. For example, in a 1931 announcement for «Courses for Policemen at the University of Southern California», Barlow, now a captain in the LAPD, is listed as offering a course on fingerprinting. The eleven lectures in the course covered the history of the system as well as identification techniques. This course, along with a list of other courses offered by the University, was announced in The American Journal of Police Science (1931, pp. 349-351). According to the announcement, the School of Citizenship and Public Administration at USC had developed a limited number of courses for police officers for the purpose of improving «the intellectual understanding of patrolmen, sergeants, lieutenants, and men on special detail about their jobs».

79. Los Angeles Examiner (20 December 1927, p. 2). Hickman had been arrested in June 1927. He had forged a number of checks while working as a page in the same bank where Perry Parker was an executive. At the time of his arrest he had claimed to be under the age of eighteen and so was 
sent to juvenile court. This would later cause some confusion as to his actual age, the implication being whether he would be eligible for the death penalty or not for the crimes of kidnapping and murdering Marion Parker. Evidence such as an employment application and Hickman's mother's testimony would put his age at over eighteen at the time of Marion's death.

80. Ibid. (20 December 1927, p. 3).

81. For story on the "scientific detective work» that led to the identification of Hickman's fingerprints, see Ibid. (21 December 1927, p. 2).

82. For a history of fingerprinting, including an excellent discussion of how cultural, political, institutional, and legal constructions helped transform the public perception of fingerprinting from that of an art into a legitimate science, see Cole (2001).

83. Los Angeles Examiner (21 December 1927, p. 2).

84. Ibid. (22 December 1927, p. 3).

85. Ibid. (21 December 1927, p. 2).

86. Ibid. (21 December 1927, p. 4).

87. "This is the link-by-link chain of evidence which so indisputably fastens guilt on the fugitive... By fingerprints, handwriting and personal identification, Hickman has been inescapably designated as the kidnap-killer. The fingerprints of Hickman himself are in the police identification bureau, as a result of his arrest last summer on forgery charges. These tally perfectly with the fingerprints on the ransom letters sent to Marion's father; on the automobile used by the kidnapper; in the apartment where he is known to have stayed. The handwriting and block-lettering in the ransom notes is declared by experts to be Hickman's, after comparison with Hickman's known printing and writing. They say there is no question» Ibid. (22 December 1927, p. 2).

88. Ibid. (22 December 1927, p. 2).

89. Ibid. (22 December 1927, p. 3).

90. «Every police agency for the dissemination of news was put into use. The telephone, telegraph, airmail - these were used more extensively than ever before to broadcast descriptions and other information to aid peace officers the land over in the grim quest. Too, arrangements were being made for airplanes, flying from Los Angeles over a wide area of surrounding communities to deliver additional police bulletins carrying complete information on the manhunt. Flying squadrons of motorcycle police delivered these bulletins to all near-by towns in all directions from Los Angeles. In Los Angeles, the concerted efforts of the police, the sheriff's office and the district attorney's office continued, with nearly 5000 trained men waging the campaign to trap 'The Fox.» In addition, an incalculable number of volunteers had entered the hunt, spurred on by the promise of tremendous rewards - perhaps near the $\$ 100,000$ mark. The American Legion broadcast orders to all members to cooperate in the search under the direction of post commanders, under a typical war-timed organization plan» Ibid. (22 December 1927, p. 2).

91. Ibid. (22 December 1927, p. 3).

92. Ibid. (22 December 1927, p. 2).

93. On the involvement of the Vancouver, B.C., police department and of those in Baja California, see stories in Ibid. (22 December 1927, p. 4); for Mexico, see Ibid. (21 December 1927, p. 2).

94. For example, the Los Angeles Examiner reported that «The spots in the Bellevue Arms apartment, known to have been occupied by Hickman until last Sunday, were positively identified as blood yesterday, according to Police Chemist Rex Welsh and Police Commissioner Thorpe. The spots were fresh - probably made last Saturday - said Welsh after microscopic analysis... County Chemist Abernathy yesterday began analysis of the candy found in the apartment. This is on the theory that the killer may have given Marion poison or a sleeping potion concealed in the chocolates. Chemical examination of the girl's body was also under way in an effort to find whether or not she had been poisoned or drugged by her captor» Los Angeles Examiner (22 December 1927, p. 2). The same story also included, as evidence, that there had been 
half a Brazil nut in Marion's coat pocket and in the apartment was found what was presumed to be its other half.

95. Ibid. (22 December 1927, p. 2).

96. Ibid. (22 December 1927, p. 3). According to the story, «Marion Parker, child victim of 'The Fox' was either dead or drugged beyond movement at the time she was brought to the Bellevue Arms Apartment by the slayer, police concluded yesterday. They made public this deduction when, after a microscopic examination of the 'single' apartment in the building at Boynton and Bellevue streets, they failed to find a single impression of the girl's fingers. Had the child been alive and able to make her way about the place, some tell-tale finger print would have been left to tell the story of her imprisonment. But from the absence of any such impression from her hand they are convinced that the child had either been murdered before being brought to the apartment or that she had been drugged into absolute immobility and remained in this condition until killed and dismembered».

97. Ibid. (22 December 1927, p. 3).

98. During the nineteenth century the French led the way in developing early methods of criminal identification with pioneers such as Francois-Eugene Vidocq (and his Brigade de la Sûreté) and Alphonse Bertillon's anthropometics. At the same time American authors such as Edgar Allan Poe and Mark Twain helped instill in the public imagination a narrative framework in which crimes were solved through the powers of logical deduction and science. See, for example, Poe's short story trilogy featuring his model detective hero C. Auguste Dupin: «The Murders in the Rue Morgue» (1841), The Mystery of Marie Roget» $(1842,1843)$, and «The Purloined Letter» (1844); and Twain's short story «The Tragedy of Pudd'nhead Wilson» (1894).

99. Los Angeles Examiner (23 December 1927, p. A).

100. A description of the fear that had taken hold over the city's mothers was recounted in a piece that appeared in the Los Angeles Examiner on 23 December 1927, p. 2. The story read that «Mother hearts of Los Angeles beat normally again last night. 'The Fox' has been caught. No other thought has ever before smitten the mothers of Los Angeles with fear and horror like the thought that a fiendish child slayer had been at large for seven days. Terror first seized the mothers of the city's children on the wings of the first news of the disappearance of little Marion Parker. Playing tots were called in from their games on the streets. Babes were more closely watched by anxious parents as they slumbered. Fright for the safety of children - all children became more intense with the receipt of the first letter of 'The Fox,' a boasting letter with threats of a horrible death that Marion Parker was facing. Anxiety of the mothers of children in Los Angeles arose to a burning pitch on Saturday night. The atrocity of the crime reached every parent with the rapidity of lightning. And from then on, until yesterday, no home felt itself safe so longs as 'The Fox' was at large to skulk along his path of diabolical murder».

101. A story recounting the evidence against Hickman provided the following: «Research Chemist Rex Welsh yesterday also discovered a hair of Marion Parker on a dresser in the apartment Edward Hickman occupied at the Bellevue Arms Apartments. The hair on the dresser was compared with hair of the girl. Checkup on the newspapers found in the apartment, together with a mass of other evidence taken from the apartment, indicated that Hickman alone murdered Marion Parker in the bathtub of Apartment 315 at the Bellevue Arms, wrapped her part in newspapers. The police, sheriff and district attorney's office believe, from the evidence collected at the apartment that Hickman was alone in the crime. Here are the points, one by one, upon which this conclusion is reached: 1 . Newspaper evidence. The newspaper of November 28 , with blood on it, was found on the floor of the bathroom. The rest of the same newspaper was found wrapped around the arms and legs of Marion Parker. A newspaper of November 27 was found on the floor of the bathroom and a section of the same paper was found in the suitcase containing parts of the body. The second section of a newspaper of December 6 was wrapped around the arms and legs. The first section was in the apartment. Sections of two afternoon 
newspapers of December 16 were around the arms and legs and other sections of the same copies were in the apartment. In the suitcase left by Hickman in front of 620 South Manhattan Place, near where he left the dismembered girl, was a section of a morning newspaper and in the apartment was another section of that same day. In the opinion of the officers the tieup [sic] of the newspapers in the apartment, with those around the body and those in the suitcase, link Hickman directly with the crime. It is the belief of the officers that Hickman killed her and mutilated her in the apartment, wrapped the body in newspapers and put some of the bundles in the suitcase to enable him to carry her away easily. 2. Bloody towels in the room. Immediately upon entering the apartment jailer Dewar and Deputy Walter Hunter found two bloody towels in the room. These indicate that Hickman used them to wipe off his hands after he washed them following the crime. Blood on the walls. 3. Two boxes of a cleaning powder were on the floor and had been used very copiously to clean the apartment and bathroom floor of blood. 4. Hickman left behind him the coat and vest of a good blue suit of clothes, destroying only the trousers. It is the belief of officers that he got his trousers bloody while dissecting the body, and therefore destroyed them. 5. Hickman's shirt was used to tie the arms of Marion Parker. 6. Improvised gloves he made from material used for tire covers apparently were put on Marion's hands to avoid leaving fingerprints. 7. Part of a hazelnut, like that found in the chemical analysis of the intestinal content, was found on the table. 8 . Tens bars of soap were partly used in the bathroom and a bar of washing soap had been almost completely used up, though Hickman was there only two weeks. 9. No one else was seen to come or go with him, according to the proprietor manager of the apartment. 10. A huge butcher knife was found in the apartment. After removing practically all the evidence, Capt. Of Detectives Herman Cline ordered the proprietor of the apartment not to permit anyone to enter it. Everything has been left intact. Yesterday the police and The Examiner again rechecked the apartment and the authorities removed all the newspapers which formed the basis of the check-up on Hickman's alibi. 11. Two of the three towels, missing from the apartment, were found wrapped around Marion Parker. 12. Hickman had practically all the money on him when the arrest was made. He had spent the rest, thus not giving any to an accomplice. Police declared Hickman was never seen around the apartment with anyone else. He frequently talked with different persons in the apartment building, but was never seen to have company by anyone who could definitely establish the fact that he had met anyone or telephoned anyone. 13. Detective Lieutenant Charles S. Johnson found a main street storekeeper who sold the grip to Hickman which was left on the South Manhattan street lawn near the scene of the delivery of the body to the father. The storekeeper is Bernard Weinstein of 247 South Main street. He said Hickman came to him some time during July or perhaps August and paid him $\$ 3$ for the grip» Ibid. (24 December 1927, p. 3).

102. Ibid. (26 December 1927, p. 2).

103. Ibid. (26 December 1927, p. 2).

104. When Hickman was first apprehended, he confessed to the crime of kidnapping but blamed the murder on an accomplice. But by December 27, newspapers were printing a new statement by Hickman in which he confessed that the accomplice was made up and that he was solely responsible for the kidnapping and murder of Marion Parker.

105. Upon Hickman's capture, «Chief of Police James E. Davis termed the apprehension of the fiendish slayer a triumph of American police methods and the American press, working as a unit in an emergency» Ibid.(23 December 1927, p. 5). 


\section{ABSTRACTS}

In the 1920s, two sensational kidnap-murders involving adolescents captured the attention of the press and the reading public: the thrill-kill of the Leopold-Loeb case and the brutal mutilation of a young girl in the Hickman case. The press representations of police workin these two cases delineate the contours of the public images of policework at a time when the police professionalization process was still incomplete. A close reading of these images provides a glimpse of the transformation process by which the police officer in the U.S. shed his early reputation as a corrupt and inept fool and re-fashioned as a trust worthy and competent professional crime-fighter.

Dans les années 1920, deux faits divers de kidnapping d'adolescents, suivis d'assassinat ont captivé la presse et les lecteurs: il s'agit du meurtre à sensation de l'affaire Leopold-Loeb et de la mutilation brutale d'une jeune fille dans l'affaire Hickman. La manière dont la presse a rendu compte du travail de la police dans ces deux affaires permet de préciser les images du travail policier dans le public à une époque où le processus de professionalisation n'est pas encore accompli. Un examen attentif de celles-ci donne un aperçu de l'évolution qui a conduit le policier américain à se défaire de sa réputation initiale d'idiot incompétent et corrompu et à revêtir celle du professionnel fiable de la lutte contre le crime.

\section{AUTHOR}

\section{PETULA IU}

UCLA, Department of History, 6265 Bunche Hall, Box 951473, Los Angeles, CA 90095-1473, piu@ucla.edu

Petula Iu received a Ph.D. in History in 2004 and is currently a part-time lecturer at UCLA. This is her first publication. Her research interests include 19th and 20th century history of crime in the U.S.; representations of the police and police work; culture and punishment; and popular culture. 